\title{
Benefits and challenges of using smart meters for advancing residential water demand modeling and management: a review
}

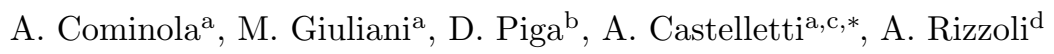 \\ ${ }^{a}$ Department of Electronics, Information, and Bioengineering, Politecnico di Milano, Milan, \\ Italy. \\ ${ }^{b} I M T$ Institute for Advanced Studies Lucca, Lucca, Italy. \\ ${ }^{c}$ Institute of Environmental Engineering, ETH Zurich, Zurich Switzerland. \\ ${ }^{d}$ Istituto Dalle Molle di Studi sull'Intelligenza Artificiale, SUPSI-USI, Lugano, Switzerland.
}

\begin{abstract}
Over the last two decades, water smart metering programs have been launched in a number of medium to large cities worldwide to nearly continuously monitor water consumption at the single household level. The availability of data at such very high spatial and temporal resolution advanced the ability in characterizing, modeling, and, ultimately, designing user-oriented residential water demand management strategies. Research to date has been focusing on one or more of these aspects but with limited integration between the specialized methodologies developed so far. This manuscript is the first comprehensive review of the literature in this quickly evolving water research domain. The paper contributes a general framework for the classification of residential water demand modeling studies, which allows revising consolidated approaches, describing emerging trends, and identifying potential future developments. In particular, the future challenges posed by growing population demands, constrained sources of water supply and climate change impacts are expected to require more and more integrated procedures for effectively supporting residential water demand modeling and management in several countries across the world.
\end{abstract}

Keywords: Smart meter, Residential water management, Water demand

\footnotetext{
${ }^{*}$ Corresponding author. Tel.: +39-02-2399-3584/7393

Email address: andrea.castelletti@polimi.it (A. Castelletti)
}

Preprint submitted to Environmental Modelling $\mathcal{G}$ Software

October 26, 2015 
modeling, Water conservation

\section{1. Introduction}

World's urban population is expected to raise from current $54 \%$ to $66 \%$ in 2050 and to further increase as a consequence of the unlikely stabilization of human population by the end of the century (Gerland et al., 2014). By 2030 the number of mega-cities, namely cities with more than 10 million inhabitants, will grow over 40 (UNDESA, 2010). This will boost residential water demand (Cosgrove and Cosgrove, 2012), which nowadays covers a large portion of the public drinking water supply worldwide (e.g., 60-80\% in Europe (Collins et al., 2010.9), 58\% in the United States (Kenny et al., 20109)).

The concentration of the water demands of thousands or millions of people into small areas will considerably raise the stress on finite supplies of available freshwater (McDonald et a.l, 201a). Besides, climate and land use change will further increase the number of people facing water shortage (McDonald et al., 2011b). In such context, water supply expansion through the construction of new infrastructures might be an option to escape water stress in some situations. Yet, geographical or financial limitations largely restrict such options in most countries (McDonald et al, 2014). Here, acting on the water demand management side through the promotion of cost-effective water-saving technologies, revised economic policies, appropriate national and local regulations, and education represents an alternative strategy for securing reliable water supply and reduce water utilities' costs (Gleick et al, 20(1)3).

In recent years, a variety of water demand management strategies (WDMS) has been applied (for a review, see Inman and Jeftrey, 2006, and references therein). However, the effectiveness of these WDMS is often context-specific and strongly depends on our understanding of the drivers inducing people to consume or save water (Jorgensen et al., 2009). Models that quantitatively describe how water demand is influenced and varies in relation to exogenous uncontrolled drivers (e.g., seasonality, climatic conditions) and demand man- 
agement actions (e.g., water restrictions, pricing schemes, education campaigns) are essential to explore water users' response to alternative WDMS, ultimately supporting strategic planning and policy design.

Traditionally, water demand models focus on different temporal and spatial scales. At the lowest resolution, studies have been carried out, mostly in the 1990s, to model water demand at the urban or block group scale, using low time resolution (i.e., above daily) consumption data retrieved through billing databases or experimental measurement campaigns on a quarterly or monthly basis. The main goal of these works is to inform regional water systems planning and management on the basis of estimated relationships between water consumption patterns and socio-economic or climatic drivers (e.g., House-Peters and Chang, 2011).

The advent of smart meters (Mayer and DeOreo, 1999) in the late 1990s made available new water consumption data at very high spatial (household) and temporal (from several minutes up to few seconds) resolution, enabling the application of data analytics tools to develop accurate characterizations of end-use water consumption profiles. Similarly to the recent developments in integrated smart solutions (Hilty et al., 2014; Laniak et al., 2013), the use of smart meters provides essential information to construct models of the individual consumers behaviors, which can be employed for designing and evaluating consumer-tailored WDMS that can more effectively modify the users' attitude favoring water saving behaviors. In particular, smart meters themselves constitute technologies that promote behavioural changes and water saving attitudes via tailored feedbacks (Fielding et al., 20113).

A general procedure to study residential water demand management relying on the high-resolution data nowadays available can be structured in the

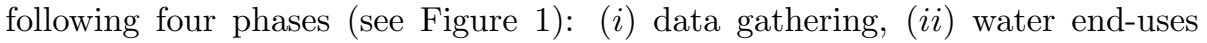
characterization, (iii) user modeling, $(i v)$ design and implementation of personalized WDMS. In the literature, a number of tools and techniques have been proposed for each of these steps, with many works focused either on the data gathering process (e.g., Cordell et al., 2003; Boyle et al., 2013) or on the anal- 
ysis of WDMS (e.g., Inman and Jettrey, 2006). Yet, to the authors' knowledge, a systematic and comprehensive review of residential water demand modeling and management is still missing. This review contributes the first effort of classification and critical analysis of 134 studies that in the last 25 years (Figure च) contributed new methodologies and tools in one or more of the steps of the above procedure (see Table $\mathbf{U}$ ).

The review is structured according to the procedure shown in Figure प: the current status, research challenges, and future directions associated to each phase are discussed in Sections $\mathbf{D} \boldsymbol{\square}$, while the last section reports final remarks and directions for follow up research.

\section{Data gathering}

Residential water consumption data gathering (box 1 in Figure $\mathbb{1}$ ) represents the first step needed to built the baseline upon which the water demand is estimated and management strategies are designed. Depending on the sampling frequency, we distinguish two main classes, namely low-resolution and highresolution data, which delimit the type of the analysis that can be performed.

\subsection{Low resolution data}

Periodically billed data are characterized by a low level of resolution and recording frequency. Although water consumption is detected with the precision of kilolitres, readings are generally recorded with the frequency of the quarter of year at most (Britton et al, 20008 ). This low resolution restricts the use of these data to regional planning, where statistical analysis estimating the amount of domestic water consumption can be used to forecast the aggregated water demand at the municipal or district level. In particular, such data have been widely used to study the effect of economic variables and seasonality on the water use at the regional scale since the seminal works by Howe and Linaweaver ([967);

Young (एप73); Berk et al (एप80); Howe (ए982); Maidment and Parzen (1.984);

Thomas and Syme (1988) (for a review see House-Peters and Chang, 201, 
and references therein). Those approaches relied on simple econometric models and time series models based on multivariate regression, and required limited datasets and low computational resources. Their main drawback is related to their limited capability of representing the spatial and temporal heterogeneity of residential water demand, which can be understood and modelled using higher resolution data. While data resolution depends on the installed meter, the logging time can be shortened without installation of smart meters but simply increasing the traditional reading frequency by the users. However, so far only ad-hoc studies systematically collected and analyzed data at daily resolution (e.g., Olmstead et al., 2007; Wong et al., 2010) and few water companies (e.g., Water Corporation in Western Australia and Thames Water in London) started increasing their reading frequency by direct involvement of their customers, who are invited to self-read their consumption and communicate it online to the water company (e.g., Anda et al., 2013).

\subsection{High resolution data}

The advent of high resolution sensors, with their ability of sampling water consumption on sub-daily basis, opened up a new potential to better characterize domestic water consumption. Two distinctive metering approaches can be distinguished: intrusive metering, which ensures direct estimates of the residential water end-uses by installing high resolution sensors on-device, namely one sensor for each water consuming appliance (e.g., washing machine, toilet flush, shower-head); non-intrusive metering, which registers the total water flow at the household level over one single detection point for the whole house.

Intrusive metering (see Rowlands et al, 2014, and references therein) is generally considered inapplicable in real-world, large-scale analysis as the number of sensors to be installed makes this approach resource intensive, costly, and hardly accepted by household occupants (Cordell et al., 2003; Kim et al., 20108). On the contrary, non-intrusive metering represents a more acceptable, though less accurate, alternative (Mayer and DeOreo, 199.9). However, this approach requires disaggregation algorithms to breakdown the total consumption data at 
the household level into the different end-use categories (see Section [3]).

Several types of sensors have been developed (Table $\boldsymbol{Z})$ by exploiting different technologies and physical properties of the water flow (for a review see Arregui et al, 20106, and references therein):

- Accelerometers (e.g., Evans et al, 20104), which analyze vibrations in a pipe induced by the turbulence of the water flow. A sampling frequency of $100 \mathrm{~Hz}$ of the pipe vibrations allows reconstructing the average flow within the pipe with a resolution of 0.015 liters (Kim et al, 20108).

- Ultrasonic sensors (Mori et al, [2004), which estimate the flow velocity, and then determine the flow rate knowing the pipe section, by measuring the difference in time between ultrasonic beams generated by piezoelectric devices and transmitted within the water flow. The transducers are generally operated in the range $0.5-2 \mathrm{MHz}$ and allow attaining an average resolution around 0.0018 liters (e.g., Sanderson and Yeung, [2002).

- Pressure sensors (Froehlich et al, [2009, 2010), which consist in steel devices, equipped with an analog-digital converter and a micro-controller, continuously sampling pressure with a theoretical maximum resolution of $2 \mathrm{kHZ}$. Flow rate is related to the pressure change generated by the opening/close of the water devices valves via Poiseuille's Law.

- Flow meters (Mayer and DeOreo, 19999), which exploit the water flow to spin either pistons (mechanic flow meters) or magnets (magnetic meters) and correlate the number of revolutions or pulse to the water volume passing through the pipe. Sensing resolution spans between 34.2 and 72 pulses per liter (i.e., 1 pulse every 0.029 and 0.014 liters, respectively) associated to a logging frequency in the range of 1 to 10 seconds (Knwalski and Marshallsay, 2005; Heinrich, 2007; Willis et al, 2013).

So far, only flow meters and pressure sensors have been employed in smart meters applications because ultrasonic sensors are too costly and the use of 
accelerometers requires an intrusive calibration phase with the placement of multiple meters distributed on the pipe network for each single device of interest (Kim et al, [2018). It is worth noting that the "smartness" of these sensors is related both to their high sampling resolution and to their integration in efficient systems combining data collection, transfer, storage, and analysis. Although sensors can be equipped with data loggers requiring human intervention to retrieve the data directly from the sensors (Mayer et al., 2004), bluetooth and wireless connections have been recently exploited for improving data management. For example, Froehlich et al (20109) installed a network of pressure sensors communicating via bluetooth with a laptop deployed at each household, which runs a custom data logger to receive, compress, and archive data. These latter are then uploaded to a web server at 30-minute intervals.

\subsection{Research challenges and future directions}

While smart meters are becoming easily available, we identified a list of open research and technical challenges that need to be addressed to promote the coherent use of this wide range of technologies:

1. The first open research question relates to the management of the metered high resolution flow data. In particular, the development of robust, automated processes to transfer the generated big data requires further elaborations, both in terms of hardware and software performance due to existing issues with respect to wireless network reliability, black spots, power source and battery life (Stewart et al, 2010; Little and Flynn, 2012). All these aspects appear key also because the possibility of integrating water and energy meters and using the same data loggers and transmission systems is expected to enhance the diffusion of high resolution water sensors (Benzi et al, 2011; Froes Lima and Portillo Navas, 2012).

2. The second open challenge concerns the design of centralized or distributed information systems to store the data collected by the smart meters (Oracle, (2009). A centralized system would allow checking the accuracy of the collected data, which can then be made easily available for data processing 
and analysis. On the contrary, a distributed solution would reduce transmission costs and facilitate providing immediate feedbacks to customers, who can use this information to make decisions about their water use.

3. A third open question is how householder privacy is impacted by collection and communication of detailed water-use information. Although such issues are currently underestimated as in many communities (e.g., in Australia) severe water shortages have led to a permissive attitude to conserve water (Giurco et al, 2010), it is likely that the collection of information on both water use and behavior change over time implies increased privacy risks (Mclntyre, 2008; Chen et al., 2014).

4. Finally, a challenge is posed by the actual deployment of large-scale highresolution metering network in the real world. While literature presents a number of trials (e.g., Mayer et al. (2004); Heinrich (2007); Froehlich et al. (200.9) ) that exploit smart sensors with extremely fine resolutions (sub-minute), cost, privacy, and regulations may limit their scalability to large-scale continuos operative smart meter installations. For example, data protection and data security issues are being seriously considered by the European Union, which is imposing some strict guidelines to utilities willing to deploy smart meter solutions for their customers and many water utilities collect data at lower resolution than the minute (e.g., Thames Water in London reads data at 15-minute resolution, EMIVASA in Valencia and SES in Switzerland at 1-hour resolution). This implies that the theoretical capabilities of smart metering technologies may not be fully exploited, potentially limiting the accuracy in characterizing the residential water consumption as studies relying on medium/low resolution data. Large-scale smart-meters application would therefore benefit from a better understanding of the consequences of different time resolutions on the models accuracy and on the effectiveness of WDMS. 


\section{Water end-uses characterization}

Non-intrusive metering requires disaggregation algorithms to breakdown the total consumption data registered at the household level into the different enduse categories (second block of Figure $\square$ ). In the water research literature, several studies have been conducted in the last two decades using a variety of single or mixed disaggregation methods, such as household auditing, diaries, high resolution flow meters and pressure sensors (see Table [1). According to the methodology adopted, we can identify two main approaches for disaggregating smart metered water data at very high temporal resolution: decision tree algorithms, namely Trace Wizard ${ }^{\circledR}$ (De()reo et all, 19996) and Identiflow ${ }^{\circledR}$ (Kowalskil and Marshallsay, (2003), and machine learning algorithms, namely HydroSense (Froehlich et aL, 2017) and SEQREUS (Beal et al, 2011a). Recently, the disaggregation of medium resolution water data (i.e., hourly data) has been explored by means of water use signature patterns method (Cardell-()liver, 2013a, ந), namely a combination of feature selection, unsupervised learning, and cluster evaluation.

\subsection{Trace Wizard}

Trace Wizard (De()reo et al, ए996) is a commercial software (recently replaced by an on-demand service developed and managed by Aquacraft Inc) which applies a decision tree algorithm to interpret magnetic metered flow data based on some basic flow boundary conditions (e.g., minimum/maximum volume, peak flow rate, duration range, etc.). The disaggregation process is structured in the following steps:

1. Conduct a detailed water device stock inventory audit for each household to determine the efficiency rating of each household appliance/fixture;

2. Household occupants should complete a diary of water use events over a one-week period to gain information on their water use habits;

3. Analysts use water audits, diaries, and sample flow trace data for each household to create specific templates that serve to match water end-use patterns depending on some basic flow boundary conditions. 
4. Based on the developed templates, stock survey audit, diary information and analysts' experience, the individual water end-uses are disaggregated.

It is worth noting that the human resource effort required by Trace Wizard makes the overall process extremely time and resource intensive, with the quality of the results that is strongly dependent on the experience of the analyst in understanding flow signatures. It has been estimated that the classification of two weeks of data approximatively requires two hours of works by the analyst and attains an average classification accuracy of 70\% ([Nguyen et al., 2013a). In addition, the prediction accuracy of Trace Wizard is significantly reduced when more than two events occur concurrently (Mayer and DeOreo, ए999). However, Trace Wizard still has an edge on disaggregation techniques and has been used in several research works and projects (DeOreo and Mayer, 1.994; Mayer and De()reo, 11995; DeOreo et al, 1996; ;Mayer and DeOreo, 11999; (DeOreo and Mayer, 2000; Loh et al, 20033; Mayer et al., 2004; Roherts, 20105; Heinrich, 20017; Mead and Aravinthan, 200.9; Willis et al., 2009a, b; Aquacraft Inc., 201]; DeOreo et al., 2(101).

\subsection{Identiflow}

Similar to Trace Wizard, Identiflow (Kowalski and Marshallsay, [2003) relies on a decision tree algorithm to perform a semi-automatic disaggregation of the total water consumption at the household level. Identiflow uses fixed physical features of various water-use devices (e.g., volume, flow rate, duration, etc.) to classify the different end-use events. Although Identiflow has shown better performance than Trace Wizard (i.e., $74.8 \%$ accuracy in terms of the correctly classified volume over 3870 events (Nguyen et al., 2013a)), its classification accuracy strongly depends on the physical features used to describe each fixture/appliance. Two different water events are likely classified into the same category if they exhibit similar physical characteristics. Moreover, it fails to classify events when old devices are replaced by modern ones, since the physical characteristics of these latter might be completely different compared to the old ones. 


\subsection{HydroSense}

HydroSense (Froehlich et al, 2011) is a probabilistic-based classification approach which relies on data collected through pressure sensors. Water end-use events are classified with respect to the unique pressure waves that propagate to the sensors when valves are opened or closed. Specifically, when a valve is opened or closed, a pressure change occurs and a pressure wave is generated in the plumbing system. Based on the pressure wave (which depends on the valve type and its location), water end-use events are classified by using advanced pattern matching algorithms and Bayesian probabilistic models. HydroSense has been demonstrated to attain very high levels of classification accuracy, namely 90\% and $94 \%$ with one or two pressure sensors, respectively (Froehlich et al, 2011). However, the calibration of the algorithm requires an intrusive monitoring period with the installation of a much larger number of pressure sensors connected to each water device (i.e., Froehlich et al. (2011) used 33 sensors in a single household). This requirement significantly constrains the portability of this approach to a wide urban context as it would entail large costs and privacy issues.

\subsection{SEQREUS}

The SEQREUS approach (Beal et aL, 2017a) proposes a combination of Hidden Markov Models (HMMs), Dynamic Time Warping (DTW), and time-ofday probability to automatically categorize the collected data at the household level into particular water end-use categories. To minimize the intrusiveness of the approach, the ground truth for the calibration (i.e., a set of disaggregated end-use events) is obtained using Trace Wizard. Then, the SEQREUS approach works as follows:

1. The disaggregated data are used for training multiple HMMs, one for each end-use category (excluding the inconclusive event);

2. The physical characteristics of each end-use category are used to refine the estimate given by the HHMs (e.g., any shower event with a volume 
less than 7 liters or any bathtub event with duration less than 4 minutes is placed in the inconclusive event for future analysis);

3. A DTW algorithm determines if any event in the inconclusive dataset is similar to an event in categories having clearly defined consumption patterns, namely the washing machine and dishwasher cycles;

4. Time of day probability is used to assign inconclusive events to an end-use category.

Testing on three independent households located in Melbourne (Australia) demonstrated a high prediction accuracy, namely between $80 \%$ and $90 \%$ for the major end-use categories ([Nguyen et al., 2014). However, the method still requires human input to achieve such levels of recognition accuracy (e.g., for the classification of inconclusive events supported by DTW and for manually classifying combine events) (guyen et al., 20113a, (1).

\subsection{Research challenges and future directions}

Given the small number of algorithms for disaggregating water flow data, there is still a large room for developing new methods addressing the major limitations of the existing approaches:

1. First, most of the approaches used in the water sector requires time consuming expert manual processing and intensive human interactions via surveys, audits and water event diaries, while the development of automatic procedures is fundamental to further extend the application of these methods beyond experimental trials and research projects (Stewart et al, 2010). Moreover, the existing methods have limited accuracy in identifying overlapping events.

The disaggregation problem has been addressed in other research fields as a general problem of blind identification, or output-only system identification (Reynders, 2012). The real state of the system (i.e., the set of the working states and water consumption of each single fixture in the household) is unknown and only observations of the system output (i.e., the 
total water consumption) are available. Starting from the 1990s, several techniques have been proposed to address blind identification problems in different research field, such as signal processing, data communication, speech recognition, image restoration, seismic signal processing (see AbedMeraim et al, 1997, and references therein).

With the development of smart electricity grids (Kramers et al,, 2014; Niesse et al., 2014), this problem has been largely studied in the energy sector to develop automatic disaggregation methods, also known as Non Intrusive Load Monitoring (NILM) algorithms, which aim at decomposing the aggregate household energy consumption data collected from a single measurement point into device-level consumption data (for a review, see Zeitman and Roth, 201]; Zoha et aL, 2012; Carrie Armel et aL, 2013, and references therein). These methods show promising results and seem effective also up to 6-10 appliances (Figueiredo et al., 2014; Makonin et al,, [2013). Yet, the portability of such techniques in the water field has not been assessed. Some additional challenges in characterizing water enduse events might be introduced by the larger human dependency than the one of electric appliances, which are more automatic. These concerns primarily involve manually controlled fixtures (e.g., bathtubs, showers, faucets), which might be used not at the maximum capacity (Froehlich et all, 200.9).

2. The second main open question relates to the acquisition of the ground truth for initial calibration. All the algorithms used for disaggregating water data, but also the majority of the ones used for energy data, need an intrusive period to collect a dataset of disaggregated end-use events, which incurs extra cost and human effort, ultimately challenging their largescale application. Researchers are actively looking to devise completely unsupervised or semi-supervised methods that avoid the effort of acquiring the calibration ground truth data (e.g., Gonçalves et al., 201]; Parson et all, (2014).

3. Finally, most of the approaches developed in the energy sector are cur- 
rently focused on correctly characterizing the on/off status of the devices and, possibly, the fraction of total energy assigned correctly, while their performance in reproducing the timings and frequencies of each device are lower (Batra et al, 2014). Yet, timings and frequencies represent key information to understand consumers behaviors and design personalized demand management strategies (e.g., deferring the use of some appliances to peak-off hours). Accordingly, knowledge about use frequencies, timing and peak-hours in the water sector would constitute crucial information for identifying both typical consumption behaviours and patterns, as well as consumption anomalies (e.g., leakages (Loureiro et al, 2014; Ponce et al, 2014; Pérez et al,, 2014; Perez et al,, 2014)). This knowledge would aid the activities of water utilities at different levels: demand management, network maintenance, and strategic planning.

\section{User modeling}

The user modeling phase (third block in Figure $\mathrm{D}$ ) aims at representing the water demand at the household level, thus preserving the heterogeneity of the individual users in the modelled community, possibly as determined by natural and socio-psychographic factors as well as by the users' response to different WDMS. In the literature, two distinctive approaches exist (see Table प): descriptive models, which limit their extent to the analysis of water consumption patterns, and predictive models, which provide estimate of the water consumption at the individual (household) level as determined by natural and socio-psychographic factors, and in response to different WDMS.

\subsection{Descriptive models}

The first class of models, namely descriptive models, aims at analyzing the observed water consumption behaviors of water users. Depending on the resolution of the data available, the analysis can focus on identifying aggregated consumption patterns or on defining users' profiles on the basis of the disaggregated end-uses (e.g., Loh et al., 2003; SI)U, 2011) S.JESD, 2011; Gato-Trinidad 
et al., 2011; Willis et al., 2011]; Beal et al., 2017b, 2013; Cardell-()liver and Peach, 2013; Cole and Stewart, 20113; Beal and Stewart, 2014; Beal et al, 2014; Gurung et al., 2014, 2015).

The construction of descriptive models allows studying historical trends (Agudelo- Vera et al., 2014; Kofinas et al, 2014) to build a user consumption profile that constitutes the baseline for identifying the most promising areas where conservation efforts may be polarized (e.g., restriction on irrigation practices in case gardening represents the dominant end-use). However, the majority of these models cannot be used to predict the water savings potential of alternative WDMS, unless combined with control group experiments to observe user responses (Cahill et al., 2013).

\subsection{Predictive models}

The second class of models, namely predictive models, aims at estimating the water demand at the individual (household) level. Some works developed predictive models that mostly provide short-term forecast of the water demand on the basis of time series analyses (e.g., Homwongs et al., 1994; Molino et al., 1996; Altunkaynak et al., 20105; Alvisi et al, 20107; Nasseri et al,, 2011). Yet, these approaches are ineffective in supporting the design and implementation of WDMS as the predicted water consumption of a user is not related to his socio-psychographic factors or his response to different WDMS. An alternative approach can be structured in the following two sub-steps: (i) multivariate analysis, which consists in the identification and selection of the most relevant inputs to explain the preselected output, and (ii) behavioral modeling, which means model structure identification, parameter calibration and validation.

The multivariate analysis phase (i.e., variable selection as called in datadriven modeling (George, [2000) ) is a fundamental step to build predictive models of urban water demand variability in space and time. In most of the works, the identification of the most relevant drivers relies on the results of data mining techniques (e.g., correlation analysis) between a pre-defined set of variables (candidate drivers) and the water consumption data. This approach is also re- 
ferred to as inductive modelling (Cahill et al., 2013). An alternative to this data-driven approach is the deductive construction of models according to empirical or theoretical causality (Cahill et al., 20133). Depending on the specific domains from which the candidate drivers are extracted, which is often delimited by data availability (Arbués et al., 2010:3), we can distinguish the following three main approaches:

- economic-driven studies, which focus on studying the correlation between water consumption and purely economic drivers, such as water tariff structures or water price elasticity (e.g., Schneider and Whitlatch, 1991; Espey et a.l, 1997; Brookshire et a.L, 2002; Dalhuisen et al., 2003; Olmstead et al., 20107; Olmstead and Stavins, 20109; Rosenberg, 2010; Qi and Chang, 2011);

- geo-spatial studies, which assess the correlation between hydro-climatic variables and seasonality with water consumption (e.g., Miaou, 1990; Griffin and Chang, 19991; Zhou et al., 2000, 20102; Fullerton and Elias, 2004; Aly and Wanakule, 2004; Gato et al., 2007; Balling and Gober, 2007; Balling et a.1, 20118; Lee and Went7, 20108; Praskievicz and Chang, 20109; Corbella and Pujol, 2009; Chang et al., 2010; Polebitski and Palmer, 2010; Lee and Wentz, 2010; Lee et al., 2011);

- psycographic-driven studies, which infer the influence of users' personal attributes on their water consumption, including income, family composition, lifestyle, and households physical characteristics (e.g., number of rooms, type, presence of garden) (e.g., Syme et al., 20(14); Wentz and Gober, 2007; Fox et al., 2009; Jorgensen et al., [2(0)9; Russell and Fielding, 2010; Grafton et aL, 2011); Willis et al, 2013; Suero et al., 2012; Matos et aL, 2014; Talebpour et al., 2014; Romano et al., 2014).

Note that this classification is not stringent, in the sense that hybrid approaches dealing with more than one of the mentioned domains have already been developed (e.g., Makki et al., 2015). Similarly to the descriptive models discussed in the previous section, the development of predictive models could 
significantly benefit from smart metering technologies and high-resolution water consumption data. Indeed, the availability of high-resolution and end-use characterization of the water consumption allows predicting the effects of customized WDMS focused on specific end-uses (e.g., Makki et al. (2013)). In most of the literature, the user modeling is limited to the multivariate analysis, which however provides only qualitative information to water managers, water utilities, and decision makers. Only few works completed the second phase (i.e., behavioral modeling) and provide a quantitative prediction of the water demand at the household level, thus representing better decision-aiding tools as they can use these models to develop what-if analysis as well as scenario simulation and analysis.

The construction of behavioral models aims at the identification, calibration, and validation of mathematical models, which describe the water demand (i.e., output variable) as a function of the drivers identified in the multivariate analysis. In the behavioral modeling literature, we can identify a first class of models, named single-user models, which describe the consumption behavior of individual users considered as isolated entities. These works (e.g., Lyman, 1992; Gato, 2006; Kenney et al., 2008; Maggioni, 2015) generally rely on dynamic models based on sampling of statistical distributions describing average users and end-uses (e.g., number of people per household and their ages, the frequency of use, flow duration and event occurrence likelihood). Water demand patterns can be then estimated via model simulation and comparison of the results with the observed data. Yet, this approach often reduces the heterogeneity of the water users, which can be preserved by running Monte Carlo simulations that sample also the extreme values of the associated statistical distributions (Rosenberg et al., 2007; Blokker et al, [2010; Cahill et al, [2013). Recently, different approaches (Bennett et al, 20133; Makki et al, 2013, 2015) combining non-parametric statistical tests and advanced regression models to identify key water consumption drivers and forecast urban water consumption have been demonstrated to successfully identify the main drivers of water consumption and to attain good forecast accuracy levels. 
A second class of behavioral models, named multi-user models, instead focus on studying the social interactions and influence/mimicking mechanisms among the users. The majority of these works relies on multiagent systems (Shoham and Leyton-Brown, 200.9), where each water user (agent) is defined as a computer system situated in some environment and capable of autonomous actions to meet its design objectives, but also able to exchange information with the neighbor agents and change its behavior accordingly (Wooldridge, 20019). The adoption of agent-based modeling offers several advantages with respect to other approaches (Bonahean, 2002; Bousquet and Le Page, 20014): (1) it provides a more natural description of a system, especially when it is composed of multiple, distributed, and autonomous agents, (2) it relaxes the hypothesis of homogeneity in a population of actually heterogeneous individuals, (3) it allows an explicit representation of spatial variability, and (4) it captures emergent global behaviors resulting from local interactions. As a consequence, multiagent systems can be employed to study the role of social network structures and mechanisms of mutual interaction and mimicking on the behaviors of water users (e.g., Rixon et al, 20107; Galán et al, 2010.9), to estimate market penetration of water-saving technologies (e.g., Chu et al, 200.9 ), and to simulate the feedbacks between water consumers and policy makers (e.g., Kanta and Zechman, [2014).

\subsection{Research challenges and future directions}

Given the current status of user modeling studies and the room for improvement given by the use of high resolution, smart metered data, several research challenges and future directions emerge:

1. The first open question in terms of descriptive models concerns matching the analysis of the water consumption patterns with the potential drivers generating the observed users' behaviors. This would allow validating the results of the classification of the users on the basis of their consumption and understanding if this latter is a good proxy representing different characteristics of the users. 
2. The use of spatially explicit models to take advantage of the high temporal and spatial resolution of smart metered data is often hindered by the aggregation of individual household data to a larger spatial scale to protect customers' privacy as well as by the difficulties in collecting and sharing data coming across multiple water authorities and administrative institutions (House-Peters and Chang, 2011).

3. The third major challenge relates to the validation of the agent-based behavioral models. As in the construction of complex process-based models, accurately describing the single user (agent) behavior and connecting multiple users within an agent-based model does not ensure the validity of the results, although these latter are contrasted with observed data. In addition, given the large number of assumption and parameters, the problem of equifinality (i.e., the potential existence of multiple, alternative parameterization leading to same simulation outcomes) has to be addressed (Ligtenberg et aI., 2010).

4. It is worth noting that the type of candidate drivers considered in the user modeling phase impacts the statistical representativeness of the results. The construction of sufficiently large datasets to estimate the relationships between water consumption data and the uncontrolled drivers (i.e., hydro-climatic and psychographic variables) is generally easy, provided that the time period is long enough and the number of involved users is sufficiently high. On the contrary, in most of the cases there is a single historical realization of the controllable drivers, namely the ones subject to human decisions (e.g., the existing pricing scheme). In such cases, the response of the users to different options is generally estimated via economics principles or surveys. Yet, economic principles introduce a priori general rules that might be inaccurate in characterizing the specific users under study, and the surveys provide only a static snapshot of the system conditions. The potential for using experimental trials (e.g., Gilg and Barr, 2006; Borisova and Useche, [2013; Fielding et al., 2013) and gamification platforms (e.g., Mühlhäuser et al, 2008) to validate behavioral 
models results by retrieving information to the real users in large-scale applications has not been tested yet.

5. Finally, a major opportunity is represented by the development of integrated models that cross-analyze water and water-related energy consumption data to improve residential water demand models (Abdallah and Rosenberg, 2014; Escriva-Bou et al., 2015b,ad).

\section{Personalized water demand management strategies}

Literature reports of a variety of management policies acting on the demand side of residential water consumption, designed with the purpose of improving water conservation and safeguarding water security in urban contexts. According to Inman and Jeffrey (20106), they can be classified in the following five categories (Table 5 ): technological, financial, legislative, maintenance, and educational. These strategies differ in the time scales they act on: price and prescriptive (i.e., command-and-control) approaches have been shown to achieve significant reductions of water demand in the short-period, but also have some drawbacks (such as equity issues and limits in consumers' price elasticity) that may limit the effectiveness of such strategies in the long term, if not integrated with other water conservation interventions (Fielding et al., 201:3; Renwick and Green, 2000). In contrast, users' awareness and educational approaches allow for smaller reductions in the short period, but appear to be crucial to pursue reductions on the long run, as they require a change in users' behaviors (Geller, $2(1) 2)$.

Technological strategies involve the installation of water efficient household appliances (e.g., Mead and Aravinthan, 200.9; Suero et a.L, 2012; Carragher et al., 2012; Froes Lima and Portillo Navas, 2012; Gurung et al., 2015). This option offers great potential for reducing indoor and outdoor water consumption (Mayer et al. 2000, 2003, 2004; De(Dreo, 2011). Yet, the benefits associated to these advanced systems are inconstant (Maggioni, 2015). For example, an incorrect use of automatic sprinkler may consume more water than manually operated 
irrigation systems (Syme et a1., 2004), thus requiring educational programs to ensure an appropriate use.

Financial strategies, (also called market-based or price approaches (0)mstead and Stavins, (20).9) ), consist in water tariffs control associated to analysis of water demand elasticity (e.g., Dandy et al., 1997; Dalhuisen et al., 20103; Arbués et al., 2003; Kenney et al., 2008; Cole et al., 2012; Molinos-Senante, 2014; Maggioni, 2015). Even though some authors claim that price-based strategies are more cost effective than other conservation programs (Olmstead and Stavins, 20109 ), the effectiveness of this strategies seems uncertain as water demand has been shown to be relatively price inelastic (Worthington and Hoffسan, 2008$)$ and to rebound to the same or even higher levels after an initial decrease (Kanakoudis, 2002). Yet, a careful assessment of the effectiveness of these strategies would benefit from longer dataset gathered in multiple jurisdictions and contexts (Worthington and Hoffman, 20108). In addition, the are also concerns about the equity of raising prices (Duke et al., 20102).

Legislative strategies correspond to mandatory regulations and restrictions on water use, particularly in case of drought (e.g., Kenney et al., 201(14; Hensher et al., 2006; Brennan et al., 2007; Kenney et al., 2008; Grafton and Ward, 20108). Restrictions applied to specific water uses, such as car washing or irrigation, have been demonstrated to reduce water consumption up to 30\% (Renwick and Archibald, 1998; Kanakoudis, 20102). However, they require policy intervention to be implemented (Maggioni, 2015) and may be resisted by the community (Steg and Vlek, 20(1)! ).

Maintenance strategies consist in operations aiming at reducing or eliminating leakages in the water supply networks (e.g., Britton et al., 20(1), 2013), which generally account for a significant fraction of the water consumption (e.g., EEAA (200I) estimated losses due to leakage equal to 30\% in Italy and 50\% in Bulgaria). The identification and repair of leakages, which are often associated to a small number of households (Roberts, 2005; Mayer and DeOreo, 1999; Mayer et al., 20(04), allows substantial increase in the efficiency of the water supply systems at lower costs with respect to augmenting the water supplied without 

622 et a.l., 2(14). et al., 2014).

repairing the network (Garcia and Thomas, 200); Brooks, 2006).

Educational strategies aim at engaging the water users by means of public awareness and education campaigns (e.g., Geller, 2002; Steg and Vlek, 200); Froes Lima and Portillo Navas, 2012; Anda et al., 2013; Fielding et al., 2013; Stewart et al, 2013). The effectiveness of these approaches is case-dependent: for example, it is estimated that information campaigns successfully led to a reduction of water demand equal to $8 \%$ in the period 1989-1996 in California (Renwick and Green, 2000), while no impact was observed in UK, where, although a large campaign involving direct mailing as well as newspaper and radio advertisements, only $5 \%$ of the 8000 residences involved noticed the campaign (Howarth and Butler, 20104). Recent studies however suggest that a relevant water saving potential can be obtained by providing feedbacks to the users about their water consumption or suggestions on customized water savings practices (e.g., Kenney et al., 2008; Willis et al., 2010; Froehlich et al., 2012; Sonderlund

Regardless the type of demand-side management strategy implemented, the availability of high-resolution data appears crucial both for the design and for an accurate evaluation of the effects of such interventions. Studies like Mayer et al. ([2000) and Mayer et al. (200:3), for instance, demonstrate that smart metered data and end-use characterization are crucial tools for evaluating the effects of retrofitting interventions both in terms of consumption reduction for particular end-uses and changes in consumption patterns (i.e., use frequencies and volumes). The same stands for price-based approaches, as smart metered data can be exploited to differentiate the price elasticity in relation to different uses (e.g., outdoor and indoor water consumption), allowing for the design of new price schemes, such as Time of Use Tariffs (Cole et all, 2012). In turn, if we consider educational campaigns, there is evidence of the potential of highresolution metering in supporting the design of effective feedbacks and assess behavioural changes (Froehlich et al., 2012; Stewart et al., 2013; Sonderlund 


\subsection{Research challenges and future directions}

Given the recent improvements in characterizing water users' behaviors, a list of open research challenges exists to improve the designed of personalized WDMS:

1. The first challenge is the identification of more effective strategies for influencing the users behaviors. Technological strategies mostly impact on a limited number of end-uses (e.g., clothes or dish washers), whereas are less effective in inducing water savings in more human-controlled end-uses, such as showering or tap water. Moreover, investment inefficiencies can limit the effectiveness of these strategies causing the Efficiency Gap that is well-known in the energy field (Allcott and Greenstone, [2012). Educational intervention and programs can be more effective in controlling these latter, for example by providing feedbacks to the users as already applied in the energy sector (e.g., Abrahamse et al., 2007; Costanza et al, 2012). Yet, there are still open questions on the use of feedbacks to reduce water (or energy) consumption, particularly with respect to the most effective feedback format, whether the effect persists over time, as well as assessments of costs and benefits of feedback (Strengers, 2011; Desley et al., (2013).

2. The second main open question relates to the long-term effect of WDMS, especially for educational programs and awareness campaigns (e.g., Peschiera et al, [2010; (Pereira et al, [2013). Although they showed promising results during the program and some months afterwards, their effect eventually dissipated and water consumption returned to pre-intervention levels after approximately 12 months (Fielding et al., 2013).

3. Finally, further effort should be devoted to examine the role of social norms and social influence in promoting water conservation (Rixon et al, 2007; Van Der Linden, 2013; Schultz et al., 2014). In particular, the potential for using gamification platforms and social applications to allow users monitoring their consumption coupled with normative information 
about similar households in their neighborhood should be assessed (Bogost, 20107; Rizzoli et al, 2014; Harom et al, 20144; Clifford et al, 20114; Curry et al., 2014; Savić et al, 2014; Vieira et al., 2014; Kossieris et al, 2014; Magiera and Froelich, 2014; Laspidou, 2014). Water utilities can indeed take advantage of people's tendency to mimic the behavior of their neighbors in order to target their efforts to "early adopters" and encourage technology diffusion (Janmaat, [2013).

\section{Discussion and conclusions}

Designing and implementing effective water demand management strategies is becoming more and more important to secure reliable water supply and reduce water utilities' costs over the next years. The advent of smart meters made available new water consumption data at very high spatial and temporal resolution, enabling a more detailed description of the drivers inducing people to consume or save water. A better understanding of water users' behaviors is indeed fundamental to promote water savings actions as it allows $(i)$ selecting the specific behaviors to be changed, (ii) examining the factors causing those behaviors, (iii) applying well-tuned interventions, and (iv) systematically evaluating the effects of these interventions on the resulting behaviors (Geller, 2002).

In this paper, we reviewed 134 papers (Table $⿴ 囗$ ) that contributed new methodologies and tools in one or more of the blocks underlying the general 4-step procedure represented in Figure $\mathbf{m}$. A "roadmap" of the main research challenges that need to be addressed in order to move the application of smart meters forward over the next decade is shown in Table $\mathbf{6}$ and summarized below:

1. Data gathering: $(i)$ how to efficiently and reliably manage the big data generated by the acquisition of high resolution smart metered flow data; (ii) understanding the best information system architecture (i.e., centralized or distributed) to store the data collected by the smart meters; (iii) how householder privacy is impacted by collection and communication of detailed water-use information; 
2. Water End-uses characterization: (i) development of automatic procedures for disaggregating water consumption data at the household level to reduce the manual processing and intensive human interactions required by current methods; (ii) development of unsupervised methods that avoid the effort of acquiring the ground truth for training the algorithms; (iii) enhancing the accuracy of the methods in reproducing the timings and frequencies of each device usage.

3. User modeling: $(i)$ matching the analysis of the observed water consumption profiles identified in the descriptive models with the potential drivers generating the observed users' behaviors; (ii) better exploit the high spatial resolution of smart metered data to identify water use patterns across geographic areas; (iii) validation of the agent-based behavioral models' simulation against observed data; (iv) testing of experimental trials and gamification platforms to support the validation of the behavioral models as well as to retrieve information from the water users; $(v)$ developing integrated models for water and water-related energy.

4. Personalized water demand management strategies: $(i)$ identification of more effective strategies for influencing the users behaviors, particularly by means of customized feedbacks to the water users providing information about their water consumption or suggestions on water savings practices; (ii) how to ensure a long-term effect of the implemented water demand management strategies, especially for educational programs and awareness campaigns; (iii) a better understanding of the role of social norms and social influence in promoting water conservation;

Despite the large number of papers published over the last years, the analysis of the studies discussed in this review highlights a clear need to shift research efforts from the development of specialized methodologies within each step of the procedure toward a more integrated approach that covers all the four phases. Indeed, the majority of the studies reviewed (i.e., $89 \%$ over 134 papers) provides contribution to a single step, whereas only few works go across multiple steps. 
Moreover, we can observe that the case study locations are not homogeneously distributed: $79 \%$ of the papers reviewed are applied in the United States $(36 \%)$ or Australia (43\%), while the remaining studies were developed in Europe $(13 \%)$ or Asia $(6 \%)$ and a single application found in South America and no one in Africa. However, we expect that the challenges posed by climate change impacts, growing population demands, and constrained sources of water supply will call for the application of integrated residential water demand modeling and management in several countries across the world. Finally, we foresee that the investments for smart technologies in fields other than urban water management (e.g., Fernndez et al., 2014; Niesse et al., 2014; Kramers et al., 2014; Rezgui et al., 2014; Zarli et al., 2014) will create opportunities for collaborations and common actions among different spheres. Residential water demand modelling and management can benefit from these collaborations because smart technologies and networks have already been deployed in other fields, like domestic energy, thus representing a benchmark for learning and integration. Moreover, the existing nexus between energy and water is expected to foster synergies and cross-influences for addressing future demands (WWAP, 2014; Escriva-Bou et al., 2015b). Integrated, interdisciplinary science will thus support policy makers and planners addressing the major sustainability challenges placed by modern urban contexts and their evolution towards smart cities (Hilty et al., 2006; Laniak et al., 2013; Letcher et al., 2013).

\section{Acknowledgements}

The work was supported by the SmartH2O: an ICT Platform to leverage on Social Computing for the efficient management of Water Consumption research project funded by the EU Seventh Framework Programme under grant agreement no. 619172 . 


\section{References}

Abdallah, A., Rosenberg, D., 2014. Heterogeneous residential water and energy linkages and implications for conservation and management. Journal of Water Resources Planning and Management 140, 288-297.

Abed-Meraim, K., Qiu, W., Hua, Y., 1997. Blind system identification. Proceedings of the IEEE 85, 1310-1322.

Abrahamse, W., Steg, L., Vlek, C., Rothengatter, T., 2007. The effect of tailored information, goal setting, and tailored feedback on household energy use, energy-related behaviors, and behavioral antecedents. Journal of Environmental Psychology 27, 265-276.

Agudelo-Vera, C., Blokker, E., Büscher, C., Vreeburg, J., 2014. Analysing the dynamics of transitions in residential water consumption in the netherlands. Water Science \& Technology: Water Supply 14, 717-727.

Allcott, H., Greenstone, M., 2012. Is there an energy efficiency gap? Technical Report. National Bureau of Economic Research.

Altunkaynak, A., Ozger, M., Cakmakci, M., 2005. Water consumption prediction of istanbul city by using fuzzy logic approach. Water Resources Management 19, 641-654. doi:10.1007/s11269-005-7371-1.

Alvisi, S., Franchini, M., Marinelli, A., 2007. A short-term, pattern-based model for water-demand forecasting. Journal of Hydroinformatics 9, 39. doi:10. $2166 /$ hydro.2006.016.

Aly, A.H., Wanakule, N., 2004. Short-term forecasting for urban water consumption. Journal of water resources planning and management 130, 405-410.

Anda, M., Le Gay Brereton, F., Brennan, J., E., P., 2013. Smart Metering Infrastructure for Residential Water Efficiency: Results of a Trial in a Behavioural Change Program in Perth, Western Australia. 
Aquacraft Inc., 2011. Albuquerque single-family water use efficiency and retrofit study. Rep. Prepared for the Albuquerque Bernalillo County Water .

Arbués, F., Garcı-Valiñas, M.Á., Martınez-Espiñeira, R., 2003. Estimation of residential water demand: a state-of-the-art review. The Journal of SocioEconomics 32, 81-102.

Arregui, F., Cabrera, E., Cobacho, R., 2006. Integrated water meter management. IWA Publishing London.

Balling, R.C., Gober, P., 2007. Climate Variability and Residential Water Use in the City of Phoenix, Arizona. Journal of Applied Meteorology and Climatology 46, 1130-1137. doi:10.1175/JAM2518.1.

Balling, R.C., Gober, P., Jones, N., 2008. Sensitivity of residential water consumption to variations in climate: an intraurban analysis of Phoenix, Arizona. Water Resources Research 44.

Batra, N., Kelly, J., Parson, O., Dutta, H., Knottenbelt, W., Rogers, A., Singh, A., Srivastava, M., 2014. NILMTK: An open source toolkit for non-intrusive load monitoring. arXiv preprint arXiv:1404.3878 .

Beal, C., Stewart, R., 2014. Identifying Residential Water End Uses Underpinning Peak Day and Peak Hour Demand. Journal of Water Resources Planning and Management 140. doi:10.1061/(ASCE)WR.1943-5452.0000357.

Beal, C., Stewart, R.A., Huang, T., Rey, E., 2011a. South east queensland residential end use study. Journal of the Australian Water Association 38, $80-84$.

Beal, C., Stewart, R.A., Spinks, A., Fielding, K., 2011b. Using smart meters to identify social and technological impacts on residential water consumption. Water Science and Technology-Water Supply 11, 527-533. doi:10.2166/ws. 2011.088. 
Beal, C.D., Makki, A., Stewart, R.A., 2014. What does rebounding water use look like? An examination of post-drought and post-flood water enduse demand in Queensland, Australia. Water Science and Technology-Water Supply 14, 561-568. doi:10.2166/ws.2014.008.

Beal, C.D., Stewart, R.A., Fielding, K., 2013. A novel mixed method smart metering approach to reconciling differences between perceived and actual residential end use water consumption. Journal of Cleaner Production 60, 116-128. doi:10.1016/j.jclepro.2011.09.007.

Bennett, C., Stewart, R.A., Beal, C.D., 2013. Ann-based residential water end-use demand forecasting model. Expert Systems with Applications 40, 1014-1023.

Benzi, F., Anglani, N., Bassi, E., Frosini, L., 2011. Electricity Smart Meters Interfacing the Households. IEEE Transactions on Industrial Electronics 58, 4487-4494. doi:10.1109/TIE.2011.2107713.

Berk, R., Cooley, T., LaCivita, C., Parker, S., Sredl, K., Brewer, M., 1980. Reducing consumption in periods of acute scarcity: the case of water. Soc. Sci. Res.;(United States) 9.

Blokker, E., Vreeburg, J., van Dijk, J., 2010. Simulating residential water demand with a stochastic end-use model. Journal of Water Resources Planning and Management 136, 19-26. doi:10.1061/(ASCE)WR.1943-5452.0000002.

Bogost, I., 2007. Persuasive games: The expressive power of videogames. Mit Press.

Bonabeau, E., 2002. Agent-based modeling: Methods and techniques for simulating human systems. Proceedings of the National Academy of Sciences of the United States of America 99, 7280-7287.

Borisova, T., Useche, P., 2013. Exploring the effects of extension workshops on household water-use behavior. HortTechnology 23, 668-676. 
Bousquet, F., Le Page, C., 2004. Multi-agent simulations and ecosystem management: a review. Ecological Modelling 176, 313-332.

Boyle, T., Giurco, D., Mukheibir, P., Liu, A., Moy, C., White, S., Stewart, R., 2013. Intelligent metering for urban water: A review. Water 5, 1052-1081.

Brennan, D., Tapsuwan, S., Ingram, G., 2007. The welfare costs of urban outdoor water restrictions. Australian Journal of Agricultural and Resource Economics 51, 243-261. doi:10.1111/j.1467-8489.2007.00395.x.

Britton, T., Cole, G., Stewart, R., Wiskar, D., 2008. Remote diagnosis of leakage in residential households. Journal of Australian Water Association 35, 89-93.

Britton, T.C., Stewart, R.A., O'Halloran, K.R., 2013. Smart metering: enabler for rapid and effective post meter leakage identification and water loss management. Journal of Cleaner Production 54, 166-176. doi:10.1016/j. jclepro.2013.05.018.

Brooks, D.B., 2006. An operational definition of water demand management. International Journal of Water Resources Development 22, 521-528. doi:10. $1080 / 07900620600779699$.

Brookshire, D.S., Burness, H.S., Chermak, J.M., Krause, K., 2002. Western urban water demand. Nat. Resources J. 42, 873.

Cahill, R., Lund, J., DeOreo, W.B., Medellín-Azuara, J., 2013. Household water use and conservation models using Monte Carlo techniques. Hydrology and Earth System Sciences Discussions 10, 4869-4900.

Cardell-Oliver, R., 2013a. Discovering water use activities for smart metering, in: Intelligent Sensors, Sensor Networks and Information Processing, 2013 IEEE Eighth International Conference on, IEEE. pp. 171-176.

Cardell-Oliver, R., 2013b. Water use signature patterns for analyzing household consumption using medium resolution meter data. Water Resources Research 49, 8589-8599. 
Cardell-Oliver, R., Peach, G., 2013. Making sense of smart metering data. Australian Water Association Water Journal 4, 124-128.

Carragher, B.J., Stewart, R.A., Beal, C.D., 2012. Quantifying the influence of residential water appliance efficiency on average day diurnal demand patterns at an end use level: A precursor to optimised water service infrastructure planning. Resources Conservation and Recycling 62, 81-90. doi:10.1016/j. resconrec. 2()1).(0).(0)8.

Carrie Armel, K., Gupta, A., Shrimali, G., Albert, A., 2013. Is disaggregation the holy grail of energy efficiency? the case of electricity. Energy Policy 52, $213-234$.

Chang, H., Parandvash, G.H., Shandas, V., 2010. Spatial Variations of SingleFamily Residential Water Consumption in Portland, Oregon. Urban Geography 31, 953-972. URL: http://dx.doi.org/10.2747/0272-3638.31.7.953, doi:10.2747/0272-3638.31.7.953.

Chen, D., Irwin, D., Shenoy, P., Albrechtt, J., 2014. Combined Heat and Privacy: Preventing Occupancy Detection from Smart Meters, in: 2014 Ieee International Conference on Pervasive Computing and Communications (percom), pp. 208-215.

Chu, J., Wang, C., Chen, J., Wang, H., 2009. Agent-based residential water use behavior simulation and policy implications: A case-study in beijing city. Water resources management 23, 3267-3295.

Clifford, E., Coakley, D., Curry, E., Degeler, V., Costa, A., Messervey, T., Van Andel, S.J., Van de Giesen, N., Kouroupetroglou, C., Mink, J., et al., 2014. Interactive water services: The waternomics approach. Procedia Engineering 89, 1058-1065.

Cole, G., O'Halloran, K., Stewart, R.A., 2012. Time of use tariffs: implications for water efficiency. Water Science and Technology-Water Supply 12, 90-100. doi:10.2166/ws.2011.123. 
Cole, G., Stewart, R.A., 2013. Smart meter enabled disaggregation of urban peak water demand: precursor to effective urban water planning. Urban Water Journal 10, 174-194. doi:10.1080/1573062X.2012.716446.

Collins, R., Kristensen, P., Thyssen, N., 2009. Water resources across Europeconfronting water scarcity and drought. Office for Official Publications of the European Communities.

Corbella, H.M., Pujol, D.S., 2009. What lies behind domestic water use?: a review essay on the drivers of domestic water consumption. Boletin de la Asociacion de Geografos Espanoles 50, 297-314.

Cordell, D., Robinson, J., Loh, M., 2003. Collecting residential end use data from primary sources: do's and dont's. Proceedings of Efficient 2003.

Cosgrove, C.E., Cosgrove, W.J., 2012. The Dynamics of Global Water Futures: Driving Forces 2011-2050. volume 2 of The United Nations World Water Development Report. UNESCO.

Costanza, E., Ramchurn, S.D., Jennings, N.R., 2012. Understanding domestic energy consumption through interactive visualisation: a field study, in: Proceedings of the 2012 ACM Conference on Ubiquitous Computing, ACM. pp. $216-225$.

Curry, E., Degeler, V., Clifford, E., Coakley, D., Costa, A., van Andel, S., van de Giesen, N., Kouroupetroglou, C., Messervey, T., Mink, J., et al., 2014. Linked water data for water information management, in: 11th International Conference on Hydroinformatics (HIC), New York, New York, USA.

Dalhuisen, J.M., Florax, R.J., de Groot, H.L., Nijkamp, P., 2003. Price and income elasticities of residential water demand: a meta-analysis. Land Economics $79,292-308$.

Dandy, G., Nguyen, T., Davies, C., 1997. Estimating residential water demand in the presence of free allowances. Land Economics , 125-139. 
DeOreo, W.B., 2011. Analysis of water use in new single family homes. By Aquacraft. For Salt Lake City Corporation and US EPA .

DeOreo, W.B., Heaney, J.P., Mayer., P.W., 1996. Flow trace analysis to assess water use. AWWA 88, 79-90.

DeOreo, W.B., Mayer, P.W., 1994. Project Report: A Process Approach for Measuring Residential Water Use and Assessing Conservation. Technical Report.

DeOreo, W.B., Mayer, P.W., 2000. The end uses of hot water in single family homes from flow trace analysis. Seattle Public Utilities and US EPA, Seattle.

DeOreo, W.B., Mayer, P.W., Martien, L., Hayden, M., Funk, A., KramerDuffield, M., Davis, R., Henderson, J., Raucher, B., Gleick, P., et al., 2011. California single-family water use efficiency study. Rep. Prepared for the California Dept. of Water Resources.

Desley, V., Laurie, B., Peter, M., 2013. The effectiveness of energy feedback for conservation and peak demand: a literature review. Open Journal of Energy Efficiency 2013.

Duke, J.M., Ehemann, R.W., Mackenzie, J., 2002. The distributional effects of water quantity management strategies: A spatial analysis. The Review of Regional Studies 32, 19-35.

EEA, 2001. Sustainable water use in Europe - Part 2: Demand Management. Technical Report Environmental issue report No.19. EEA - European Environment Agency.

Escriva-Bou, A., Lund, J.R., Pulido-Velazquez, M., 2015a. Modeling residential water and related energy, carbon footprint and costs in california. Environmental Science \& Policy 50, 270-281.

Escriva-Bou, A., Lund, J.R., Pulido-Velazquez, M., 2015b. Optimal residential water conservation strategies considering related energy in california. Water Resources Research. 
Espey, M., Espey, J., Shaw, W.D., 1997. Price elasticity of residential demand for water: A meta-analysis. Water Resources Research 33, 1369-1374.

Evans, R.P., Blotter, J.D., Stephens, A.G., 2004. Flow rate measurements using flow-induced pipe vibration. Journal of fluids engineering 126, 280-285.

Fernndez, C., Many, F., Mateu, C., Sole-Mauri, F., 2014. Modeling energy consumption in automated vacuum waste collection systems. Environmental Modelling \& Software 56, 63 - 73. doi:http://dx.doi.org/10.1016/j. envsoft. 2013.11.013. thematic issue on Modelling and evaluating the sustainability of smart solutions.

Fielding, K.S., Spinks, A., Russell, S., McCrea, R., Stewart, R.A., Gardner, J., 2013. An experimental test of voluntary strategies to promote urban water demand management. Journal of environmental management 114, 343-351.

Figueiredo, M., Ribeiro, B., de Almeida, A., 2014. Electrical signal source separation via nonnegative tensor factorization using on site measurements in a smart home. Instrumentation and Measurement, IEEE Transactions on 63, 364-373. doi:10.1109/TIM.2013.2278596.

Fox, C., McIntosh, B., Jeffrey, P., 2009. Classifying households for water demand forecasting using physical property characteristics. Land Use Policy 26, 558 - 568. doi:http://dx.doi.org/10.1016/j.landusepol.2008.08.004.

Froehlich, J., Findlater, L., Ostergren, M., Ramanathan, S., Peterson, J., Wragg, I., Larson, E., Fu, F., Bai, M., Patel, S., Landay, J.A., 2012. The design and evaluation of prototype eco-feedback displays for fixture-level water usage data, in: Proceedings of the SIGCHI Conference on Human Factors in Computing Systems, ACM, New York, NY, USA. pp. 2367-2376.

Froehlich, J., Larson, E., Saba, E., Campbell, T., Atlas, L., Fogarty, J., Patel, S., 2011. A longitudinal study of pressure sensing to infer real-world water usage events in the home, in: Pervasive Computing. Springer, pp. 50-69. 
Froehlich, J.E., Larson, E., Campbell, T., Haggerty, C., Fogarty, J., Patel, S.N., 2009. Hydrosense: Infrastructure-mediated single-point sensing of whole-home water activity, in: Proceedings of the 11th International Conference on Ubiquitous Computing, ACM, New York, NY, USA. pp. 235-244. doi:10.1145/1620545.1620581.

Froes Lima, C.A., Portillo Navas, J.R., 2012. Smart metering and systems to support a conscious use of water and electricity. Energy 45, 528-540. doi:10.1016/j.energy.2012.02.033.

Fullerton, T.M., Elias, A., 2004. Short-term water consumption dynamics in El Paso, Texas. Water Resources Research 40.

Galán, J., López-Paredes, A., Del Olmo, R., 2009. An agent-based model for domestic water management in valladolid metropolitan area. Water Resources Research 45 .

Garcia, S., Thomas, A., 2001. The structure of municipal water supply costs: Application to a panel of french local communities. Journal of Productivity Analysis 16, 5-29. doi:10.1023/A:1011142901799.

Gato, S., 2006. Forecasting urban residential water demand. Ph.D. thesis. School of Civil, Environmental and Chemical Engineering, RMIT University.

Gato, S., Jayasuriya, N., Roberts, P., 2007. Temperature and rainfall thresholds for base use urban water demand modelling. Journal of Hydrology 337, 364 -376 .

Gato-Trinidad, S., Jayasuriya, N., Roberts, P., 2011. Understanding urban residential end uses of water. Water Science \& Technology 64 .

Geller, E.S., 2002. The challenge of increasing proenvironment behavior, in: Handbook of environmental psychology. Wiley: New York, NY, USA. chapter 34 , pp. 525-540. 
George, E.I., 2000. The variable selection problem. Journal of the American Statistical Association 95, 1304-1308.

Gerland, P., Raftery, A.E., evikova, H., Li, N., Gu, D., Spoorenberg, T., Alkema, L., Fosdick, B.K., Chunn, J., Lalic, N., Bay, G., Buettner, T., Heilig, G.K., Wilmoth, J., 2014. World population stabilization unlikely this century. Science 346, 234-237. doi:10.1126/science.1257469.

Giacomoni, M., Berglund, E., 2015. Complex adaptive modeling framework for evaluating adaptive demand management for urban water resources sustainability. Journal of Water Resources Planning and Management, 04015024.

Gilg, A., Barr, S., 2006. Behavioural attitudes towards water saving? evidence from a study of environmental actions. Ecological Economics 57, 400-414.

Giurco, D.P., White, S.B., Stewart, R.A., 2010. Smart metering and water end-use data: conservation benefits and privacy risks. Water 2, 461-467.

Gleick, P.H., Haasz, D., Henges-Jeck, C., Srinivas, V., Wolff, G., Cushing, K.K., Mann, A., 2003. Waste not, want not: The potential for urban water conservation in California. Pacific Institute for Studies in Development, Environment, and Security Oakland, CA.

Gonçalves, H., Ocneanu, A., Bergés, M., Fan, R., 2011. Unsupervised disaggregation of appliances using aggregated consumption data, in: The 1st KDD Workshop on Data Mining Applications in Sustainability (SustKDD).

Grafton, R.Q., Ward, M.B., 2008. Prices versus Rationing: Marshallian Surplus and Mandatory Water Restrictions. Economic Record 84, S57-S65. doi:10. $1111 / j .1475-4932.2008 .00483 . x$.

Grafton, R.Q., Ward, M.B., To, H., Kompas, T., 2011. Determinants of residential water consumption: Evidence and analysis from a 10-country household survey. Water Resources Research 47. doi:10.1029/2010WR009685. 
Griffin, R.C., Chang, C., 1991. Seasonality in community water demand. Western Journal of Agricultural Economics 16, 207-217.

Gurung, T.R., Stewart, R.A., Beal, C.D., Sharma, A.K., 2015. Smart meter enabled water end-use demand data: enhanced infrastructure planning of contemporary supply networks platform for the urban water supply networks. Journal of Cleaner Production 87, 642-654. doi:10.1016/j.jclepro.2014. 0.9 .054$.

Gurung, T.R., Stewart, R.A., Sharma, A.K., Beal, C.D., 2014. Smart meters for enhanced water supply network modelling and infrastructure planning. Resources Conservation and Recycling 90, 34-50. doi:10.1016/j.resconrec. 2014.06 .005 .

Harou, J., Garrone, P., Rizzoli, A., Maziotis, A., Castelletti, A., Fraternali, P., Novak, J., Wissmann-Alves, R., Ceschi, P., 2014. Smart metering, water pricing and social media to stimulate residential water efficiency: Opportunities for the smarth2o project. Procedia Engineering 89, 1037-1043.

Heinrich, M., 2007. Water End Use and Efficiency Project (WEEP) - Final Report. BRANZ Study Report 159.

Hensher, D., Shore, N., Train, K., 2006. Water supply security and willingness to pay to avoid drought restrictions. Economic Record 82, 56-66. doi:10. $1111 / j .1475-4932.2006 .00293 . x$.

Hilty, L.M., Aebischer, B., Rizzoli, A.E., 2014. Modeling and evaluating the sustainability of smart solutions. Environmental Modelling \& Software 56, 1 - 5. doi:http://dx.doi.org/10.1016/j.envsoft.2014.04.001. thematic issue on Modelling and evaluating the sustainability of smart solutions.

Hilty, L.M., Arnfalk, P., Erdmann, L., Goodman, J., Lehmann, M., Wger, P.A., 2006. The relevance of information and communication technologies for environmental sustainability? a prospective simulation study. Environmental 
Modelling \& Software 21, 1618 - 1629. doi:http://dx.doi.org/10.1016/j. envsoft. 2006.05.007. environmental Informatics.

Homwongs, C., Sastri, T., Foster III, J.W., 1994. Adaptive forecasting of hourly municipal water consumption. Journal of water resources planning and management 120, 888-905.

House-Peters, L.A., Chang, H., 2011. Urban water demand modeling: Review of concepts, methods, and organizing principles. Water Resources Research 47.

Howarth, D., Butler, S., 2004. Communicating water conservation: how can the public be engaged? Water Science \& Technology: Water Supply 4, 33-44.

Howe, C.W., 1982. The impact of price on residential water demand: Some new insights. Water Resources Research 18, 713-716.

Howe, C.W., Linaweaver, F.P., 1967. The impact of price on residential water demand and its relation to system design and price structure. Water Resources Research 3, 13-32.

Inman, D., Jeffrey, P., 2006. A review of residential water conservation tool performance and influences on implementation effectiveness. Urban Water Journal 3, 127-143.

Janmaat, J., 2013. Spatial patterns and policy implications for residential water use: An example using kelowna, british columbia. Water Resources and Economics 1, 3-19. doi:10.1016/j.wre.2013.03.003.

Jorgensen, B., Graymore, M., O'Toole, K., 2009. Household water use behavior: An integrated model. Journal of Environmental Management 91, 227 - 236.

Kanakoudis, V., 2002. Urban water use conservation measures. Aqua- Journal of Water Supply: Research and Technology 51, 153-163. 
Kanta, L., Zechman, E., 2014. Complex Adaptive Systems Framework to Assess Supply-Side and Demand-Side Management for Urban Water Resources. Journal of Water Resources Planning and Management 140, 75-85. doi:10.1061/(ASCE)WR .1943-5452.0000301.

Kenney, D.S., Goemans, C., Klein, R., Lowrey, J., Reidy, K., 2008. Residential Water Demand Management: Lessons from Aurora, Colorado. JAWRA Journal of the American Water Resources Association 44, 192-207. doi:10. $1111 / \mathrm{j} .1752-1688.2007 .00147 . \mathrm{x}$.

Kenney, D.S., Klein, R.A., Clark, M.P., 2004. Use and Effectiveness of Municipal Water Restrictions During Drought in Colorado. JAWRA Journal of the American Water Resources Association 40, 77-87. doi:10.1111/j. $1 /(52 .-1688.2004 \cdot t h 01011 \cdot x$.

Kenny, J.F., Barber, N.L., Hutson, S.S., Linsey, K.S., Lovelace, J.K., Maupin, M.A., 2009. Estimated use of water in the United States in 2005. US Geological Survey Reston, VA.

Kim, Y., Schmid, T., Charbiwala, Z.M., Friedman, J., Srivastava, M.B., 2008. Nawms: nonintrusive autonomous water monitoring system, in: Proceedings of the 6th ACM conference on Embedded network sensor systems, ACM. pp. 309-322.

Kofinas, D., Mellios, N., Papageorgiou, E., Laspidou, C., 2014. Urban water demand forecasting for the island of skiathos. Procedia Engineering 89, 10231030.

Kossieris, P., Panayiotakis, A., Tzouka, K., Gerakopoulou, P., Rozos, E., Makropoulos, C., 2014. An elearning approach for improving household water efficiency. Procedia Engineering 89, 1113-1119.

Kowalski, M., Marshallsay, D., 2003. A system for improved assessment of domestic water use components, International Water Association. 
Kowalski, M., Marshallsay, D., 2005. Using measured microcomponent data to model the impact of water conservation strategies on the diurnal consumption profile. Water Science \& Technology: Water Supply 5.

Kramers, A., Hjer, M., Lvehagen, N., Wangel, J., 2014. Smart sustainable cities ? exploring $\{\mathrm{ICT}\}$ solutions for reduced energy use in cities. Environmental Modelling \& Software 56, 52 - 62. doi:http://dx.doi.org/10. 1016/j.envsoft.2013.12.019. thematic issue on Modelling and evaluating the sustainability of smart solutions.

Laniak, G.F., Olchin, G., Goodall, J., Voinov, A., Hill, M., Glynn, P., Whelan, G., Geller, G., Quinn, N., Blind, M., Peckham, S., Reaney, S., Gaber, N., Kennedy, R., Hughes, A., 2013. Integrated environmental modeling: A vision and roadmap for the future. Environmental Modelling \& Software 39, 3 - 23. doi:http://dx.doi.org/10.1016/j.envsoft.2012.09.006. thematic Issue on the Future of Integrated Modeling Science and Technology.

Laspidou, C., 2014. Ict and stakeholder participation for improved urban water management in the cities of the future .

Lee, M., Tansel, B., Balbin, M., 2011. Influence of residential water use efficiency measures on household water demand: A four year longitudinal study. Resources, Conservation and Recycling 56, 1 - 6. doi:http: //dx.doi.org/10.1016/j.resconrec.2011.08.006.

Lee, S.J., Wentz, E.A., 2008. Applying Bayesian Maximum Entropy to extrapolating local-scale water consumption in Maricopa County, Arizona. Water Resources Research 44.

Lee, S.J., Wentz, E.A., 2010. Effects of urban spatial structure, sociodemographics, and climate on residential water consumption in Hillsboro, Oregon. Journal of American Water Resources Association 46, 461-472.

Letcher, R.A.K., Jakeman, A.J., Barreteau, O., Borsuk, M.E., ElSawah, S., Hamilton, S.H., Henriksen, H.J., Kuikka, S., Maier, H.R., Rizzoli, A.E., van 
Delden, H., Voinov, A.A., 2013. Selecting among five common modelling approaches for integrated environmental assessment and management. Environmental Modelling \& Software 47, 159 - 181. doi:http://dx.doi.org/10. $1016 / j$. envsoft.2013.05.005.

Ligtenberg, A., van Lammeren, R.J.A., Bregt, A.K., Beulens, A.J.M., 2010. Validation of an agent-based model for spatial planning: A role-playing approach. Computers, Environment and Urban Systems 34, 424-434. doi:10. $1016 / j$. compenvurbsys.2010.04.005.

Little, L., Flynn, J., 2012. Big Data, Smart Meters \& Australian Water Utilities. Technical Report.

Loh, M., Coghlan, P., Australia, W., 2003. Domestic water use study: In Perth, Western Australia, 1998-2001. Water Corporation.

Loureiro, D., Alegre, H., Coelho, S., Martins, A., Mamade, A., 2014. A new approach to improve water loss control using smart metering data. Water Science \& Technology: Water Supply 14, 618-625.

Lyman, R.A., 1992. Peak and off-peak residential water demand. Water Resources Research 28, 2159-2167.

Maggioni, E., 2015. Water demand management in times of drought: What matters for water conservation. Water Resources Research doi:10.1002/ 2014WR.016301.

Magiera, E., Froelich, W., 2014. Integrated support system for efficient water usage and resources management (iss-ewatus). Procedia Engineering 89, 1066-1072.

Maidment, D.R., Parzen, E., 1984. Cascade model of monthly municipal water use. Water Resources Research 20, 15-23.

Makki, A.A., Stewart, R.A., Beal, C.D., Panuwatwanich, K., 2015. Novel bottom-up urban water demand forecasting model: Revealing the determi- 
nants, drivers and predictors of residential indoor end-use consumption. Resources, Conservation and Recycling 95, 15-37. doi:10.1016/j.resconrec. 2014.11.009.

Makki, A.A., Stewart, R.A., Panuwatwanich, K., Beal, C., 2013. Revealing the determinants of shower water end use consumption: enabling better targeted urban water conservation strategies. Journal of Cleaner Production 60, 129146. doi:10.1016/j.jclepro.2011.08.007.

Makonin, S., Popowich, F., Bartram, L., Gill, B., Bajic, I.V., 2013. AMPds: A public dataset for load disaggregation and eco-feedback research, in: 2013 IEEE Conference on Electrical Power \& Energy Conference (EPEC), IEEE. pp. 1-6.

Matos, C., Teixeira, C.A., Bento, R., Varajao, J., Bentes, I., 2014. An exploratory study on the influence of socio-demographic characteristics on water end uses inside buildings. Science of The Total Environment 466-467, 467-474. doi:10.1016/j.scitotenv.2013.07.036.

Mayer, P.W., DeOreo, W.B., 1995. Process approach for measuring residential water use and assessing conservation effectiveness, AWWA.

Mayer, P.W., DeOreo, W.B., 1999. Residential end uses of water. American Water Works Association.

Mayer, P.W., Deoreo, W.B., Lewis, D.M., 2000. Seattle home water conservation study: The impacts of high efficiency plumbing fixture retrofits in singlefamily homes. Technical Report. Seattle Public Utilities and USEPA. Boulder, Colorado.

Mayer, P.W., Deoreo, W.B., Towler, E., Lewis, D.M., 2003. Residential indoor water conservation study: Evaluation of high efficiency indoor plumbing fixture retrofits in single-family homes in the East Bay municipal utility district (EDMUD) service area. Technical Report. The United States Environmental Protection Agency. 
Mayer, P.W., DeOreo, W.B., Towler, E., Martien, L., Lewis, D., 2004. Tampa water department residential water conservation study: the impacts of high efficiency plumbing fixture retrofits in single-family homes. A Report Prepared for Tampa Water Department and the United States Environmental Protection Agency

McDonald, R., Douglas, I., Grimm, N., Hale, R., Revenga, C., Gronwall, J., Fekete, B., 2011a. Implications of fast urban growth for freshwater provision. Ambio 40, 437.

McDonald, R., Green, P., Balk, D., Fekete, B., Revenga, C., Todd, M., Montgomery, M., 2011b. Urban growth, climate change, and freshwater availability. Proceedings of the National Academy of Sciences 108, 6312-6317. doi:10.1073/pnas.1011615108.

McDonald, R.I., Weber, K., Padowski, J., Flörke, M., Schneider, C., Green, P.A., Gleeson, T., Eckman, S., Lehner, B., Balk, D., Boucher, T., Grill, G., Montgomery, M., 2014. Water on an urban planet: Urbanization and the reach of urban water infrastructure. Global Environmental Change 27, 96 105. doi:http://dx.doi.org/10.1016/j.gloenvcha.2014.04.022.

McIntyre, T., 2008. Data retention in Ireland: Privacy, policy and proportionality. Computer Law \& Security Review 24, 326-334.

Mead, N., Aravinthan, V., 2009. Investigation of household water consumption using smart metering system. Desalination and Water Treatment 11, 115-123. doi:10.5004/dwt.2009.850.

Miaou, S.P., 1990. A class of time series urban water demand models with nonlinear climatic effects. Water Resources Research 26, 169-178.

Molino, B., Rasulo, G., Taglialatela, L., 1996. Forecast model of water consumption for naples. Water resources management 10, 321-332. 
Molinos-Senante, M., 2014. Water rate to manage residential water demand with seasonality: peak-load pricing and increasing block rates approach. Water Policy 16, 930-944.

Mori, M., Tezuka, K., Tezuki, H., 2004. Ultrasonic flow meter, flow measurement method, and computer program. US Patent App. 10/584,318.

Mühlhäuser, M., Gurevych, I., Global, I., 2008. Handbook of research on ubiquitous computing technology for real time enterprises. Information Science Reference.

Nasseri, M., Moeini, A., Tabesh, M., 2011. Forecasting monthly urban water demand using extended kalman filter and genetic programming. Expert Systems with Applications 38, 7387-7395. doi:10.1016/j.eswa.2010.12.087.

Nguyen, K., Stewart, R., Zhang, H., 2013b. An intelligent pattern recognition model to automate the categorisation of residential water end-use events. Environmental Modelling \& Software 47, 108-127. doi:10.1016/j.envsoft. 2013.05 .002$.

Nguyen, K.A., Stewart, R.A., Zhang, H., 2014. An autonomous and intelligent expert system for residential water end-use classification. Expert Systems with Applications 41, 342-356. doi:10.1016/j.eswa.2013.07.049.

Nguyen, K.A., Zhang, H., Stewart, R.A., 2013a. Development of an intelligent model to categorise residential water end use events. Journal of Hydroenvironment Research 7, 182 - 201. doi:http://dx.doi.org/10.1016/j. jher.2013.02.004.

Niesse, A., Trschel, M., Sonnenschein, M., 2014. Designing dependable and sustainable smart grids ? how to apply algorithm engineering to distributed control in power systems. Environmental Modelling \& Software 56, 37 51. doi:http://dx.doi.org/10.1016/j.envsoft.2013.12.003. thematic issue on Modelling and evaluating the sustainability of smart solutions. 
Olmstead, S.M., Michael Hanemann, W., Stavins, R.N., 2007. Water demand under alternative price structures. Journal of Environmental Economics and Management 54, 181-198.

Olmstead, S.M., Stavins, R.N., 2009. Comparing price and nonprice approaches to urban water conservation. Water Resources Research 45.

Oracle, 2009. Smart Metering for Water Utilities. Technical Report.

Parson, O., Ghosh, S., Weal, M., Rogers, A., 2014. An unsupervised training method for non-intrusive appliance load monitoring. Artificial Intelligence 217, 1 - 19. doi:http://dx.doi.org/10.1016/j.artint.2014.07.010.

Pereira, L., Quintal, F., Barreto, M., Nunes, N.J., 2013. Understanding the limitations of eco-feedback: A one-year long-term study, in: Human-Computer Interaction and Knowledge Discovery in Complex, Unstructured, Big Data. Springer, pp. 237-255.

Pérez, R., Cugueró, M.A., Cugueró, J., Sanz, G., 2014. Accuracy assessment of leak localisation method depending on available measurements. Procedia Engineering 70, 1304-1313.

Perez, R., Sanz, G., Puig, V., Quevedo, J., Cuguero Escofet, M.A., Nejjari, F., Meseguer, J., Cembrano, G., Mirats Tur, J.M., Sarrate, R., 2014. Leak localization in water networks: A model-based methodology using pressure sensors applied to a real network in barcelona [applications of control]. Control Systems, IEEE 34, 24-36.

Peschiera, G., Taylor, J.E., Siegel, J.A., 2010. Response-relapse patterns of building occupant electricity consumption following exposure to personal, contextualized and occupant peer network utilization data. Energy and Buildings $42,1329-1336$.

Polebitski, A.S., Palmer, R.N., 2010. Seasonal residential water demand forecasting for census tracts. Journal of Water Resources Planning and Management 136, 27-36. 
Ponce, M.V.C., Castañón, L.E.G., Cayuela, V.P., et al., 2014. Model-based leak detection and location in water distribution networks considering an extended-horizon analysis of pressure sensitivities. Journal of Hydroinformatics 16, 649-670.

Praskievicz, S., Chang, H., 2009. Identifying the Relationships Between Urban Water Consumption and Weather Variables in Seoul, Korea. Physical Geography 30, 324-337. doi:10.2747/0272-3646.30.4.324.

Qi, C., Chang, N.B., 2011. System dynamics modeling for municipal water demand estimation in an urban region under uncertain economic impacts. Journal of Environmental Management 92, 1628-1641. doi:10.1016/j.jenvman. 2011.01 .020 .

Renwick, M.E., Archibald, S.O., 1998. Demand side management policies for residential water use: who bears the conservation burden? Land economics, 343-359.

Renwick, M.E., Green, R.D., 2000. Do residential water demand side management policies measure up? an analysis of eight california water agencies. Journal of Environmental Economics and Management 40, 37 - 55 . doi:http://dx.doi.org/10.1006/jeem.1999.1102.

Reynders, E., 2012. System identification methods for (operational) modal analysis: review and comparison. Archives of Computational Methods in Engineering 19, 51-124.

Rezgui, Y., Zarli, A., Ellis, K.A., McCann, J.A., 2014. Optimized water demand management through intelligent sensing and analytics: The wisdom approach, in: 11th International Conference on Hydroinformatics (HIC) 2014, New York City, USA.

Rixon, A., Moglia, M., Burn, S., 2007. Exploring water conservation behaviour through participatory agent based modelling. Topics on Systems Analysis for Integrated Water Resource Management. 
Rizzoli, A., Castellettib, A., Cominolab, A., Fraternalib, P., dos Santos, A.D., Storni, B., Wissmann-Alvese, R., Bertocchi, M., Novak, J., Micheelg, I., 2014. The smarth2o project and the role of social computing in promoting efficient residential water use: a first analysis, in: Proceedings of the 7th International Congress on Environmental Modelling and Software.

Roberts, P., 2005. Yarra Valley Water: 2004 residential end use measurement study. Technical Report. Yarra Valley Water Melbourne. Melbourne, Australia.

Romano, G., Salvati, N., Guerrini, A., 2014. Estimating the determinants of residential water demand in italy. Water 6, 2929-2945. doi:10.3390/w6102929.

Rosenberg, D., 2010. Residential water demand under alternative rate structures: Simulation approach. Journal of Water Resources Planning and Management 136, 395-402. doi:10.1061/(ASCE)WR.1943-5452.0000046.

Rosenberg, D.E., Tarawneh, T., Abdel-Khaleq, R., Lund, J.R., 2007. Modeling integrated water user decisions in intermittent supply systems. Water Resources Research 43, W07425. doi:10.1029/2006WR005340.

Rowlands, I.H., Reid, T., Parker, P., 2014. Research with disaggregated electricity end-use data in households: review and recommendations. Wiley Interdisciplinary Reviews: Energy and Environment URL: http://dx.doi.org/ 10.1002/wene.151, doi:10.1002/wene.151.

Russell, S., Fielding, K., 2010. Water demand management research: A psychological perspective. Water Resources Research 46, W05302. doi:10.1029/ 2009WR008408.

Sanderson, M.L., Yeung, H., 2002. Guidelines for the use of ultrasonic noninvasive metering techniques. Flow Measurement and Instrumentation 13, 125-142. doi:10.1016/S0955-5986(02)00043-2. 
Savić, D., Vamvakeridou-Lyroudia, L., Kapelan, Z., 2014. Smart meters, smart water, smart societies: The iwidget project. Procedia Engineering 89, 11051112.

Schneider, M., Whitlatch, E., 1991. User-specific water demand elasticities. Journal of Water Resources Planning and Management 117, 52-73. doi:10. 1061/(ASCE)0733-9496(1991)117:1(52).

Schultz, P.W., Messina, A., Tronu, G., Limas, E.F., Gupta, R., Estrada, M., 2014. Personalized Normative Feedback and the Moderating Role of Personal Norms A Field Experiment to Reduce Residential Water Consumption. Environment and Behavior, 0013916514553835.

SDU, 2011. Urban Water Management Plan 2010. Technical Report. City of Sacramento, Sacramento, California.

Shoham, Y., Leyton-Brown, K., 2009. Multiagent Systems: Algorithmic, GameTheoretic, and Logical Foundations. Princeton University Press.

SJESD, 2011. Urban Water Management Plan. Technical Report. City of San Jose, Sacramento, California.

Sonderlund, A.L., Smith, J.R., Hutton, C., Kapelan, Z., 2014. Using Smart Meters for Household Water Consumption Feedback: Knowns and Unknowns. Procedia Engineering 89, 990-997. doi:10.1016/j.proeng.2014.11.216.

Steg, L., Vlek, C., 2009. Encouraging pro-environmental behaviour: An integrative review and research agenda. Journal of Environmental Psychology 29, 309-317. doi:10.1016/j.jenvp.2008.10.004.

Stewart, R.A., Willis, R., Giurco, D., Panuwatwanich, K., Capati, G., 2010. Web-based knowledge management system: linking smart metering to the future of urban water planning. Australian Planner 47, 66-74. doi:10.1080/ $0 / 293681003 / 6 / 169$. 
Stewart, R.A., Willis, R.M., Panuwatwanich, K., Sahin, O., 2013. Showering behavioural response to alarming visual display monitors: longitudinal mixed method study. Behaviour \& Information Technology 32, 695-711. doi:10. 1080/0144929X.2011.577195.

Strengers, Y., 2011. Negotiating everyday life: The role of energy and water consumption feedback. Journal of Consumer Culture 11, 319-338. doi:10. $1177 / 1469540511417994$.

Suero, F., Mayer, P., Rosenberg, D., 2012. Estimating and verifying united states households' potential to conserve water. Journal of Water Resources Planning and Management 138, 299-306.

Syme, G.J., Shao, Q., Po, M., Campbell, E., 2004. Predicting and understanding home garden water use. Landscape and Urban Planning 68, 121 - 128. doi:http://dx.doi.org/10.1016/j.landurbplan.2003.08.002.

Talebpour, M., Sahin, O., Siems, R., Stewart, R., 2014. Water and energy nexus of residential rain water tanks at an end use level: Case of australia. Energy and Buildings.

Thomas, J.F., Syme, G.J., 1988. Estimating residential price elasticity of demand for water: A contingent valuation approach. Water Resources Research $24,1847-1857$.

UNDESA, 2010. World urbanization prospects: The 2014 Revision. Highlights (ST/ESA/SER.A/352). United Nations Department of Economic and Social Affairs Population Division.

Van Der Linden, S., 2013. Exploring beliefs about bottled water and intentions to reduce consumption: The dual-effect of social norm activation and persuasive information. Environment and Behavior, 0013916513515239.

Vieira, P., Loureiro, D., Barateiro, J., Ribeiro, R., Rebelo, M., Coelho, S.T., 2014. Innovative smart metering-based applications for water utilities. Water Utility Management International 9, 16. 
Wentz, E.A., Gober, P., 2007. Determinants of small-area water consumption for the city of phoenix, arizona. Water Resources Management 21, 1849-1863.

Willis, R., Stewart, R.A., Panuwatwanich, K., Capati, B., Giurco, D., 2009b. Gold coast domestic water end use study. Water 36, 79-85.

Willis, R.M., Stewart, R.A., Capati, B., 2009a. Closing the loop on water planning: an integrated smart metering and web-based knowledge management system approach, in: ICA 2009, International Water Association.

Willis, R.M., Stewart, R.A., Giurco, D.P., Telebpour, M.R., Mousavinejad, A., 2013. End use water consumption in households: impact of socio-demographic factors and efficient devices. Journal of Cleaner Production 60, 107 - 115. doi:http://dx.doi.org/10.1016/j.jclepro.2011.08.006. special Volume: Water, Women, Waste, Wisdom and Wealth.

Willis, R.M., Stewart, R.A., Panuwatwanich, K., Jones, S., Kyriakides, A., 2010. Alarming visual display monitors affecting shower end use water and energy conservation in australian residential households. Resources, Conservation and Recycling 54, 1117 - 1127.

Willis, R.M., Stewart, R.A., Panuwatwanich, K., Williams, P.R., Hollingsworth, A.L., 2011. Quantifying the influence of environmental and water conservation attitudes on household end use water consumption. Journal of Environmental Management 92, 1996-2009. doi:10.1016/j.jenvman.2011.03.023.

Wong, J.S., Zhang, Q., Chen, Y.D., 2010. Statistical modeling of daily urban water consumption in hong kong: Trend, changing patterns, and forecast. Water Resources Research 46. doi:10.1029/2009WR008147.

Wooldridge, M., 2009. An Introduction to MultiAgent Systems. Second ed., Wiley, NY.

Worthington, A.C., Hoffman, M., 2008. An empirical survey of residential water demand modelling. Journal of Economic Surveys 22, 842-871. 
WWAP, 2014. The United Nations World Water Development Report 2014: Water and Energy. Paris, UNESCO.

Young, R.A., 1973. Price elasticity of demand for municipal water: A case study of tucson, arizona. Water Resources Research 9, 1068-1072.

Zarli, A., Rezgui, Y., Belziti, D., Duce, E., 2014. Water analytics and intelligent sensing for demand optimised management: The wisdom vision and approach. Procedia Engineering 89, 1050-1057.

Zeifman, M., Roth, K., 2011. Nonintrusive appliance load monitoring: Review and outlook. IEEE Transactions on Consumer Electronics 57, 76-84.

Zhou, S.L., McMahon, T.A., Walton, A., Lewis, J., 2000. Forecasting daily urban water demand: a case study of melbourne. Journal of Hydrology 236, $153-164$.

Zhou, S.L., McMahon, T.A., Walton, A., Lewis, J., 2002. Forecasting operational demand for an urban water supply zone. Journal of Hydrology 259, 189-202. doi:10.1016/S0022-1694(01)00582-0.

Zoha, A., Gluhak, A., Imran, M.A., Rajasegarar, S., 2012. Non-intrusive load monitoring approaches for disaggregated energy sensing: A survey. Sensors $12,16838-16866$. 
Table 1: Details of the papers reviewed.

\begin{tabular}{|c|c|c|c|c|c|}
\hline Reference & Location & $\begin{array}{l}\text { Data } \\
\text { gathering }\end{array}$ & $\begin{array}{c}\text { Water } \\
\text { end-uses }\end{array}$ & $\begin{array}{c}\text { User } \\
\text { modeling }\end{array}$ & $\begin{array}{l}\text { Personalized } \\
\text { WDMS }\end{array}$ \\
\hline Anda et al. (20I3) & Australia & $\mathrm{x}$ & & & \\
\hline Boyle et al. (20113) & $\mathrm{N} / \mathrm{A}$ & $\mathrm{x}$ & & & \\
\hline Willis et al. (2013) & Australia & $\mathrm{x}$ & & $\mathrm{x}$ & \\
\hline Frroehlich et a.l. (20ll) & $\mathrm{N} / \mathrm{A}$ & $\mathrm{x}$ & $\mathrm{x}$ & & \\
\hline Wong et al. (2010) & Hong Kong & $\mathrm{x}$ & & & \\
\hline Froehlich et al. (201).9) & $\mathrm{N} / \mathrm{A}$ & $\mathrm{x}$ & & & \\
\hline Kim et a.1. (2008) & $\mathrm{N}^{\prime} / \mathrm{A}$ & $\mathrm{x}$ & & & \\
\hline Heinrich (20107) & New Zeland & $\mathrm{x}$ & $\mathrm{x}$ & & \\
\hline Olmstead et al. (ख0107) & USA & $\mathrm{x}$ & & $\mathrm{x}$ & \\
\hline Kowalski and Marshallsay (2005) & UK & $\mathrm{x}$ & $\mathrm{x}$ & & \\
\hline Evans et al. (2004) & $\mathrm{N} / \mathrm{A}$ & $\mathrm{x}$ & & & \\
\hline Mayer et al. (20104) & USA & $\mathrm{x}$ & $\mathrm{x}$ & & $\mathrm{x}$ \\
\hline Mori et a.L (2004) & $\mathrm{N} / \mathrm{A}$ & $\mathrm{x}$ & & & \\
\hline Cordell et al. (20103) & Australia & $\mathrm{x}$ & & & \\
\hline Sanderson and Yeung ( 20102$)$ & $\mathrm{N} / \mathrm{A}$ & $\mathrm{x}$ & & & \\
\hline Mayer and DeOreo (19999) & USA & $\mathrm{x}$ & & & $\mathrm{x}$ \\
\hline Nguyen et al. (2014) & Australia & & $\mathrm{x}$ & & \\
\hline Nguyen et al. (2013a) & Australia & & $\mathrm{x}$ & & \\
\hline Nguyen et al. (201:3b) & Australia & & $\mathrm{x}$ & & \\
\hline Cardell-(Oliven (2013a) & Australia & & $\mathrm{x}$ & & \\
\hline Cardell-()liven (2013b) & Australia & & $\mathrm{x}$ & & \\
\hline Aquacraft Inc. (खणा) & USA & & $\mathrm{x}$ & & \\
\hline Beal et a.l (201|a) & Australia & & $\mathrm{x}$ & & \\
\hline De(Oreo et al. ([201]) & USA & & $\mathrm{x}$ & & \\
\hline Mead and Aravinthan (2009) & Australia & & $\mathrm{x}$ & & \\
\hline Willis et al. (2009a) & Australia & & $\mathrm{x}$ & & \\
\hline Willis et al. (2009b) & Australia & & $\mathrm{x}$ & & \\
\hline Roberts (20115) & Australia & & $\mathrm{x}$ & & $\mathrm{x}$ \\
\hline Kowalski and Marshallsay (2010:3) & UK & & $\mathrm{x}$ & & \\
\hline Loh et al. ([2003) & Australia & & $\mathrm{x}$ & $\mathrm{x}$ & \\
\hline DeOreo and Mayer ([2000) & USA & & $\mathrm{x}$ & & \\
\hline De(Oreo et al. (19.96) & USA & & $\mathrm{x}$ & & \\
\hline Mayer and DeOreo (109.5) & USA & & $\mathrm{x}$ & & \\
\hline DeOreo and Mayer (11.9.94) & USA & & $\mathrm{x}$ & & \\
\hline Makki et al (20I5) & Australia & & & $\mathrm{x}$ & \\
\hline Beal et al. (2014) & Australia & & & $\mathrm{x}$ & \\
\hline Kanta and Kechman (2014) & $\mathrm{N} / \mathrm{A}$ & & & $\mathrm{x}$ & \\
\hline Beal and Stewart (2014) & Australia & & & $\mathrm{x}$ & \\
\hline Matos et al. (2014) & Portugal & & & $\mathrm{x}$ & \\
\hline Talebpour et al. (2014) & Australia & & & $\mathrm{x}$ & \\
\hline Romano et al. (2UI4) & Italy & & & $\mathrm{x}$ & \\
\hline Cardell-()liver and Peach (2010:3) & Australia & & & $\mathrm{x}$ & \\
\hline Beal et al. (201:3) & Australia & & & $\mathrm{x}$ & \\
\hline Bennett et al. (2013) & Australia & & & $\mathrm{x}$ & \\
\hline Cahill et al. (2013) & USA & & & $\mathrm{x}$ & \\
\hline Cole and Stewart (2013) & Australia & & & $\mathrm{x}$ & \\
\hline Makki et al. (2013) & Australia & & & $\mathrm{x}$ & \\
\hline Beal et al (2077b) & Australia & & & $\mathrm{x}$ & \\
\hline Gato-'Trinidad et al. ([0II) & Australia & & & $\mathrm{x}$ & \\
\hline Grafton et al. (20II) & 10 OECD countries & & & $\mathrm{x}$ & \\
\hline House-Peters and Chang (201I) & $\mathrm{N} / \mathrm{A}$ & & & $\mathrm{x}$ & \\
\hline Lee et al. (2011) & USA & & & $\mathrm{x}$ & \\
\hline Nasseri et al. (20II) & Iran & & & $\mathrm{x}$ & \\
\hline Qi and Chang (20II) & USA & & & $\mathrm{x}$ & \\
\hline SI) $(2010)$ & USA & & & $\mathrm{x}$ & \\
\hline S.IFEII) (खणIT) & USA & & & $\mathrm{x}$ & \\
\hline Willis et al. (201]) & Australia & & & $\mathrm{x}$ & \\
\hline Blokker et a.l. (20]0) & Nederland & & & $\mathrm{x}$ & \\
\hline Chang et al. (ZणI0) & USA & & & $\mathrm{x}$ & \\
\hline Lee and Wentz (ZUII) & USA & & & $\mathrm{x}$ & \\
\hline Polebitski and Palmer (20I0) & USA & & & $\mathrm{x}$ & \\
\hline Rosenberg (खणII) & Jordan & & & $\mathrm{x}$ & \\
\hline Russell and Fielding (2010) & $\mathrm{N} / \mathrm{A}$ & & & $\mathrm{x}$ & \\
\hline
\end{tabular}


Table 1: (Continued) Details of the papers reviewed.

\begin{tabular}{|c|c|c|c|c|c|}
\hline Reference & Location & $\begin{array}{l}\text { Data } \\
\text { gathering }\end{array}$ & $\begin{array}{l}\text { Water } \\
\text { end-uses }\end{array}$ & $\begin{array}{c}\text { User } \\
\text { modeling }\end{array}$ & $\begin{array}{c}\text { Personalized } \\
\text { WDMS }\end{array}$ \\
\hline Chul et al (20109) & China & & & $\mathrm{x}$ & \\
\hline Corbella and Pujol (20109) & $\mathrm{N} / \mathrm{A}$ & & & $\mathrm{x}$ & \\
\hline Fox et al. (2009) & UK & & & $\mathrm{x}$ & \\
\hline Galán et al. (20109) & Spain & & & $\mathrm{x}$ & \\
\hline Jorgensen et al. (ZU०,. & $\mathrm{N} / \mathrm{A}$ & & & $\mathrm{x}$ & \\
\hline Olmstead and Stavins (2001) & N/A & & & $\mathrm{x}$ & \\
\hline Praskievicz and Chang (200M) & Korea & & & $\mathrm{x}$ & \\
\hline Balling et al. (20108) & USA & & & $\mathrm{x}$ & \\
\hline Lee and Wentz (2018) & USA & & & $\mathrm{x}$ & \\
\hline Alvisi et al. (2007) & Italy & & & $\mathrm{x}$ & \\
\hline Balling and Gober (2007) & USA & & & $\mathrm{x}$ & \\
\hline Gato et al. (2007) & Australia & & & $\mathrm{x}$ & \\
\hline Rosenberg et al. (2007) & Jordan & & & $\mathrm{x}$ & \\
\hline Wentz and Gober (2017) & USA & & & $\mathrm{x}$ & \\
\hline Gato (20106) & Australia & & & $\mathrm{x}$ & \\
\hline Altunkaynak et al. (2005) & Turkey & & & $\mathrm{x}$ & \\
\hline Fullerton and Eilias (2004) & USA & & & $\mathrm{x}$ & \\
\hline Aly and Wanakule (2004) & USA & & & $\mathrm{x}$ & \\
\hline Syme et al. (20104) & Australia & & & $\mathrm{x}$ & \\
\hline Brookshire et al. (2002) & $\mathrm{N} / \mathrm{A}$ & & & $\mathrm{x}$ & \\
\hline Zhoul et al (20100) & Australia & & & $\mathrm{x}$ & \\
\hline Zholl et al (20102) & Australia & & & $\mathrm{x}$ & \\
\hline Espey et al. (11.997) & $\mathrm{N} / \mathrm{A}$ & & & $\mathrm{x}$ & \\
\hline Molino et al. (1.996) & Italy & & & $\mathrm{x}$ & \\
\hline Homwongs et al. (11994) & USÄ & & & $\mathrm{x}$ & \\
\hline Lyman (1.9.92) & USA & & & $\mathrm{x}$ & \\
\hline Grittin and Chang (199.9I) & USA & & & $\mathrm{x}$ & \\
\hline Rixon et al (20107) & Australia & & & $\mathrm{x}$ & \\
\hline Schneider and Whitlatch (II99I) & USA & & & $\mathrm{x}$ & \\
\hline Miaoul (11990) & USA & & & $\mathrm{x}$ & \\
\hline Maggioni (2U15) & USA & & & & $\mathrm{x}$ \\
\hline Sonderlund et al. (2U14) & $\mathrm{N} / \mathrm{A}$ & & & & $\mathrm{x}$ \\
\hline Molinos-Senante (2014) & Spain & & & & $\mathrm{x}$ \\
\hline Britton et al (2013) & Australia & & & & $\mathrm{x}$ \\
\hline Fielding et al. (2013) & Australia & & & & $\mathrm{x}$ \\
\hline Stewart et al. (2013) & Australia & & & & $\mathrm{x}$ \\
\hline Carragher et al. (2012) & Australia & & & & $\mathrm{x}$ \\
\hline Cole et al. (2012) & Australia & & & & $\mathrm{x}$ \\
\hline Froehlich et al. (ZUIZ) & USA & & & & $\mathrm{x}$ \\
\hline Froes Lima and Portillo Navas (2012) & Brazil & & & & $\mathrm{x}$ \\
\hline De(Oren (《III) & USA & & & & $\mathrm{x}$ \\
\hline Willis et al (20II) & Australia & & & & $\mathrm{x}$ \\
\hline Mead and Aravinthan (200) & Australia & & & & $\mathrm{x}$ \\
\hline Steg and Vlek (200.9) & $\mathrm{N} / \mathrm{A}$ & & & & $\mathrm{x}$ \\
\hline Britton et al. (ZUण) & Australia & & & & $\mathrm{x}$ \\
\hline Grafton and Ward (2008) & Australia & & & & $\mathrm{x}$ \\
\hline Worthington and Hottman (2008) & $\mathrm{N} / \mathrm{A}$ & & & & $\mathrm{x}$ \\
\hline Brennan et al (20107) & Australia & & & & $\mathrm{x}$ \\
\hline Brooks $(2006)$ & $\mathrm{N} / \mathrm{A}$ & & & & $\mathrm{x}$ \\
\hline Hensher et all (2006) & Australia & & & & $\mathrm{x}$ \\
\hline Inman and Jettrey (2006) & $\mathrm{N} / \mathrm{A}$ & & & & $\mathrm{x}$ \\
\hline Howarth and Butler (2004) & UK & & & & $\mathrm{x}$ \\
\hline Arbués et al. (20103) & $\mathrm{N} / \mathrm{A}$ & & & & $\mathrm{x}$ \\
\hline Duke et al. (ZUणz) & USA & & & & $\mathrm{x}$ \\
\hline Gellen (20112) & $\mathrm{N} / \mathrm{A}$ & & & & $\mathrm{x}$ \\
\hline Garcia and Thomas (200) & France & & & & $\mathrm{x}$ \\
\hline Kanakoudis (20102) & Greece & & & & $\mathrm{x}$ \\
\hline Renwick and Green ([2000) & USA & & & & $\mathrm{x}$ \\
\hline Renwick and Archibald (19.98) & USA & & & & $\mathrm{x}$ \\
\hline Dandy et al. (11997) & Australia & & & & $\mathrm{x}$ \\
\hline Gurung et al. (201.5) & Australia & & & $\mathrm{x}$ & $\mathrm{x}$ \\
\hline Gurung et al. (2014) & Australia & & & $\mathrm{x}$ & \\
\hline Suero et al (2012) & USA & & & $\mathrm{x}$ & $\mathrm{x}$ \\
\hline
\end{tabular}


Table 1: (Continued) Details of the papers reviewed.

\begin{tabular}{|c|c|c|c|c|c|}
\hline Reference & Location & $\begin{array}{c}\text { Data } \\
\text { gathering }\end{array}$ & $\begin{array}{l}\text { Water } \\
\text { end-uses }\end{array}$ & $\begin{array}{c}\text { User } \\
\text { modeling }\end{array}$ & $\begin{array}{l}\text { Personalized } \\
\text { WDMS }\end{array}$ \\
\hline Giacomoni and Berglund (20I.5) & USA & & & $\mathrm{x}$ & $\mathrm{x}$ \\
\hline Eiscriva-Boll et al (2015a) & USA & & & $\mathrm{x}$ & $\mathrm{x}$ \\
\hline Escriva-Boul et al (2015b) & USA & & & $\mathrm{x}$ & $\mathrm{x}$ \\
\hline Kenney et al. (2008) & USA & & & $\mathrm{x}$ & $\mathrm{x}$ \\
\hline Kenney et al. (20104) & USA & & & & $\mathrm{x}$ \\
\hline Dalhuisen et al. (20103) & $\mathrm{N} / \mathrm{A}$ & & & $\mathrm{x}$ & $\mathrm{x}$ \\
\hline Mayer et aI. (20103) & USA & $\mathrm{x}$ & $\mathrm{x}$ & & $\mathrm{x}$ \\
\hline Mayer et al. (20100) & USA & $\mathrm{x}$ & $\mathrm{x}$ & & $\mathrm{x}$ \\
\hline
\end{tabular}


Table 2: Studies contributing in the data gathering step. Studies gathering data with a sub-daily resolution are considered as high-resolution, low-resolution otherwise.

\begin{tabular}{|c|c|c|c|c|}
\hline Reference & Location & Resolution & Sensor Type & Resolution[liters] \\
\hline Olmstead et all (2007) & USA & low & - & - \\
\hline Wong et al. (सणI0) & Hong Kong & low & - & - \\
\hline Anda et al. (2013) & Australia & low & - & - \\
\hline Boyle et al. (2013) & $\mathrm{N} / \mathrm{A}$ & high & - & - \\
\hline Cordell et al. (20103) & Australia & high & - & - \\
\hline Kim et al. (सU118) & $\mathrm{N} / \mathrm{A}$ & high & accelerometer & 0.0150 \\
\hline Mayer and DeOreo (10999) & USA & high & flow meter & $0.014-0.029$ \\
\hline Evans et al. (2004) & $\mathrm{N} / \mathrm{A}$ & high & accelerometer & 0.0150 \\
\hline Mori et al (20114) & $\mathrm{N} / \mathrm{A}$ & high & ultrasonic & 0.0018 \\
\hline Sanderson and Yeung ( (2002) & $\mathrm{N} / \mathrm{A}$ & high & ultrasonic & 0.0018 \\
\hline Froehlich et al. (2009) & $\mathrm{N} / \mathrm{A}$ & high & pressure & 0.0600 \\
\hline Froehlich et al. (सUII) & $\mathrm{N} / \mathrm{A}$ & high & pressure & 0.0600 \\
\hline Kowalski and Marshallsay (200.5) & UK & high & flow meter & $0.014-0.029$ \\
\hline Heinrich (एण117) & New Zeland & high & flow meter & $0.014-0.029$ \\
\hline Willis et al (20113) & Australia & high & flow meter & $0.014-0.029$ \\
\hline Mayer et al. (2004) & USA & high & flow meter & $0.014-0.029$ \\
\hline Mayer et al. (2000 & USA & high & flow meter & $0.014-0.029$ \\
\hline Mayer et al. (20103) & USA & high & flow meter & $0.014-0.029$ \\
\hline
\end{tabular}


Table 3: Studies contributing in the water end-uses characterization step.

\begin{tabular}{|c|c|c|c|}
\hline Reference & Location & Disaggregation algorithm & Number of households \\
\hline Froehlich et all (खणII) & $\mathrm{N} / \mathrm{A}$ & HydoSense & 5 \\
\hline Heinrich (एपणा) & New Zeland & Trace Wizard & 12 \\
\hline Mayer et al. (स्2014) & USA & Trace Wizard & 33 \\
\hline De()ren et al (10996) & USA & Trace Wizard & $\mathrm{N} / \mathrm{A}$ \\
\hline Kowalski and Marshallsay (20013) & UK & Identiflow & 250 \\
\hline Kowalski and Marshallsay (200.5) & UK & Identiflow & $\mathrm{N} / \mathrm{A}$ \\
\hline Beal et all (एणIa) & Australia & SEQREUS & 1500 \\
\hline DeUreo and Mayer (1994) & USA & Trace Wizard & 16 \\
\hline Mayer and DeOred (1199.5) & USA & Trace Wizard & 16 \\
\hline 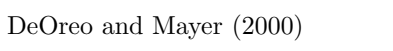 & USA & Trace Wizard & 10 \\
\hline Loh et all $(20003)$ & Australia & Trace Wizard & 720 \\
\hline Roberts (2001.5) & Australia & Trace Wizard & 100 \\
\hline Mead and Aravinthan (20109) & Australia & Trace Wizard & 10 \\
\hline Willis et al (20104a) & Australia & Trace Wizard & 200 \\
\hline Willis et all (2009b) & Australia & Trace Wizard & 151 \\
\hline Aquacraft Inc. (एणI) & USA & Trace Wizard & 209 \\
\hline Nguyen et al. (खा14) & Australia & SEQREUS & 3 \\
\hline Nguyen et al. (2याउa) & Australia & SEQREUS & 252 \\
\hline Nguyen et al. (2013b) & Australia & SEQREUS & 3 (out of 252 ) \\
\hline Mayer et al. (एव101) & USA & Trace Wizard & 37 (out of 1188 ) \\
\hline Mayer et al. (200.3) & USA & Trace Wizard & 33 \\
\hline DeOred (खणI) & USA & Trace Wizard & 1000 \\
\hline Cardell-Oliver (2013.3a) & Australia & Water Use Signature Patterns & 11000 \\
\hline Cardell-() liven (2017:3W) & Australia & Water Use Signature Patterns & 187 \\
\hline
\end{tabular}


Table 4: Studies contributing in the user modeling step. Legend for multivariate analysis approaches: $\mathrm{E}=$ economic-driven; $\mathrm{GS}=$ geo-spatial; $\mathrm{P}=$ psychographic driven; $\mathrm{AR}=$ autoregressive. Legend for behavioural models approach: single $=$ single user model; multi $=$ multi-user model .

\begin{tabular}{|c|c|c|c|c|c|}
\hline Reference & Location & $\begin{array}{l}\text { Modeling } \\
\text { approach }\end{array}$ & $\begin{array}{c}\text { Multivariate } \\
\text { analysis }\end{array}$ & $\begin{array}{l}\text { Behavioural } \\
\text { model }\end{array}$ & $\begin{array}{l}\text { Spatial } \\
\text { scale }\end{array}$ \\
\hline Loh et a.L. (2003) & Australia & descriptive & - & - & household \\
\hline Gato-'Trinidad et a.l (20II) & Australia & descriptive & - & - & household \\
\hline SIDU (खणा & USA & descriptive & - & - & household \\
\hline S.JESD ( 2011$)$ & USA & descriptive & - & - & household \\
\hline Cardell-(Oliver and Peach (2013) & Australia & descriptive & - & - & household \\
\hline Beal et al. (2013) & Australia & descriptive & - & - & household \\
\hline Beal and Stewart (2014) & Australia & descriptive & - & - & household \\
\hline Gurung et al. (2015) & Australia & descriptive & - & - & household \\
\hline Gurung et al. (2014) & Australia & descriptive & - & - & household \\
\hline Beal et a.L (2014) & Australia & descriptive & - & - & household \\
\hline Cole and Stewart (2013) & Australia & descriptive & - & - & household \\
\hline Willis et al. (20I]) & Australia & descriptive & - & - & household \\
\hline Beal et al. (2017b) & Australia & descriptive & - & - & household \\
\hline Maggionı (LUI5) & USA & predictive & $\mathrm{E}+\mathrm{GS}+\mathrm{P}$ & single & household \\
\hline Makki et al. (2015) & Australia & predictive & $\mathrm{E}+\mathrm{P}$ & single & household \\
\hline House-Peters and Chang (खणI) & $\mathrm{N} / \mathrm{A}$ & predictive & $\mathrm{E}+\mathrm{GS}+\mathrm{P}$ & single + multi & $\mathrm{N} / \mathrm{A}$ \\
\hline Schneider and Whitlatch (I99T) & USA & predictive & $\mathrm{E}$ & - & district \\
\hline Lyman (19.92) & USA & predictive & $\mathrm{E}+\mathrm{GS}+\mathrm{P}$ & single & household \\
\hline Espey et al. (11997) & $\mathrm{N} / \mathrm{A}$ & predictive & $\mathrm{E}$ & - & $\mathrm{N} / \mathrm{A}$ \\
\hline Dalhuisen et al. (2003) & $\mathrm{N} / \mathrm{A}$ & predictive & $\mathrm{E}$ & - & $\mathrm{N} / \mathrm{A}$ \\
\hline Miaou (1990) & USA & predictive & GS & - & urban \\
\hline Polebitski and Palmer (2010) & USA & predictive & GS & - & census tracts \\
\hline Lee et al] (201T) & USA & predictive & GS & - & household \\
\hline Olmstead et al. (2007) & USA & predictive & $\mathrm{E}$ & - & household \\
\hline Willis et al. (2013) & Australia & predictive & $\mathrm{P}$ & - & household \\
\hline Homwongs et al. (1.994) & USA & predictive & $\mathrm{AR}$ & - & urban \\
\hline Molino et al. (1996) & Italy & predictive & $\mathrm{AR}$ & - & urban \\
\hline Altunkaynak et al. (200.5) & Turkey & predictive & AR & - & urban \\
\hline Alvisi et al. (20107) & Italy & predictive & $\mathrm{AR}$ & - & household \\
\hline Nasseri et all (एतII) & Iran & predictive & $\mathrm{AR}$ & - & urban \\
\hline Brookshire et al. ([20(1)2) & $\mathrm{N} / \mathrm{A}$ & predictive & $\mathrm{E}$ & - & $\mathrm{N} / \mathrm{A}$ \\
\hline Olmstead and Stavins (200) & $\mathrm{N} / \mathrm{A}$ & predictive & $\mathrm{E}$ & - & $\mathrm{N} / \mathrm{A}$ \\
\hline Rosenberg (2010) & Jordan & predictive & $\mathrm{E}$ & - & household \\
\hline Qi and Chang (20II) & USA & predictive & $\mathrm{E}$ & - & urban \\
\hline Grittin and Chang (1991) & USA & predictive & GS & - & district \\
\hline Zhoul et al (2000) & Australia & predictive & GS & - & urban \\
\hline Zhou et al. (2002) & Australia & predictive & GS & - & district \\
\hline Fullerton and Elias (20104) & USA & predictive & GS & - & urban \\
\hline Aly and Wanakule (20(1)4) & USA & predictive & GS & - & urban \\
\hline Gato et al. (20107) & Australia & predictive & GS & - & urban \\
\hline Balling and Gober (2007) & USA & predictive & GS & - & urban \\
\hline Balling et al. (2008) & USA & predictive & GS & - & census tracts \\
\hline Lee and Wentz (खाI8) & USA & predictive & GS & - & census tracts \\
\hline Praskievicz and Chang (2009) & Korea & predictive & GS & - & urban \\
\hline Corbella and Pujol (20109) & $\mathrm{N} / \mathrm{A}$ & predictive & GS & - & $\mathrm{N} / \mathrm{A}$ \\
\hline Chang et al. (Z2010) & USA & predictive & GS & - & household \\
\hline Lee and Wentz (ZUI0) & USA & predictive & GS & - & urban \\
\hline Syme et al. (20104) & Australia & predictive & $\mathrm{P}$ & - & household \\
\hline Wentz and (tober (20107) & USA & predictive & $\mathrm{P}$ & - & household \\
\hline Fox et all (20109) & UK & predictive & $\mathrm{P}$ & - & household \\
\hline Russell and Fielding (2010) & $\mathrm{N} / \mathrm{A}$ & predictive & $\mathrm{P}$ & - & $\mathrm{N} / \mathrm{A}$ \\
\hline Grafton et al. (201]) & 10 OECD countries & predictive & $\mathrm{P}$ & - & household \\
\hline Suero et al. (2Uाए2) & USA & predictive & $\mathrm{P}$ & - & household \\
\hline Matos et al. (2014) & Portugal & predictive & $\mathrm{P}$ & - & household \\
\hline Talebpour et al. (2014) & Australia & predictive & $\mathrm{P}$ & - & household \\
\hline Bomano et a.L (2014) & Italy & predictive & $\mathrm{P}$ & - & water utility \\
\hline Gato (2006) & Australia & predictive & GS & single & urban \\
\hline
\end{tabular}


Table 4: (Continued) Studies contributing in the user modeling step.

\begin{tabular}{|c|c|c|c|c|c|}
\hline Reference & Location & $\begin{array}{l}\text { Modeling } \\
\text { approach }\end{array}$ & $\begin{array}{c}\text { Multivariate } \\
\text { analysis }\end{array}$ & $\begin{array}{l}\text { Behavioural } \\
\text { model }\end{array}$ & $\begin{array}{l}\text { Spatial } \\
\text { scale }\end{array}$ \\
\hline Rosenberg et al. (20177) & Jordan & predictive & $\mathrm{GS}+\mathrm{P}$ & single & household \\
\hline Blokker et al (खणII) & Nederland & predictive & $\mathrm{P}$ & single & household \\
\hline Cahill et al. (2013) & USA & predictive & $\mathrm{P}$ & single & household \\
\hline Bennett et al. ([2013) & Australia & predictive & $\mathrm{GS}+\mathrm{E}+\mathrm{P}$ & single & household \\
\hline Rixon et al. (यUण & Australia & predictive & $\mathrm{E}+\mathrm{P}$ & multi & household \\
\hline Galán et al. (2009) & Spain & predictive & $\mathrm{P}$ & multi & household \\
\hline Chu et al. (2009) & China & predictive & $\mathrm{E}+\mathrm{P}$ & multi & household \\
\hline Kanta and Kechman (2014) & $\mathrm{N} / \mathrm{A}$ & predictive & $\mathrm{GS}+\mathrm{P}$ & multi & household \\
\hline Jorgensen et al. ([200.9) & $\mathrm{N} / \mathrm{A}$ & predictive & $\mathrm{P}$ & - & household \\
\hline Kenney et al. (201)8) & USA & predictive & $\mathrm{E}+\mathrm{GS}+\mathrm{P}$ & single & household \\
\hline Makki et al. (2013) & Australia & predictive & $\mathrm{E}+\mathrm{P}$ & single & household \\
\hline Giacomoni and Berglund (2015) & USA & predictive & GS & multi & urban \\
\hline Escriva-Boul et al. (2015a) & USA & predictive & $\mathrm{P}$ & single & household \\
\hline ? & USA & predictive & $\mathrm{P}$ & single & household \\
\hline
\end{tabular}


Table 5: Studies contributing in the personalized WDMS step. Different WDMS are considered: $\mathrm{E}=$ educational; $\mathrm{F}=$ financial; $\mathrm{L}=$ legislative; $\mathrm{M}=$ maintenance; $\mathrm{T}=$ technological.

\begin{tabular}{|c|c|c|c|}
\hline Reference & Location & Type of WDMS & Personalized \\
\hline Maggion! (सया?) & USA & $\mathrm{L}+\mathrm{T}+\mathrm{F}$ & $\mathrm{x}$ \\
\hline 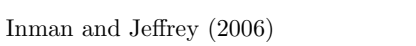 & $\mathrm{N} / \mathrm{A}$ & $\mathrm{T}+\mathrm{F}+\mathrm{L}+\mathrm{M}+\mathrm{E}$ & \\
\hline Britton et all (खण18) & Australia & M & $\mathrm{x}$ \\
\hline Dalhulsen et all (स्या13) & $\mathrm{N} / \mathrm{A}$ & $\mathrm{E}$ & \\
\hline Mayer and DeOreo (II999) & USA & M & $\mathrm{x}$ \\
\hline Mayer et al. (2ख114) & USA & $\mathrm{T}+\mathrm{M}$ & $\mathrm{x}$ \\
\hline Roberts (2011.5) & Australia & $\mathrm{M}$ & $\mathrm{x}$ \\
\hline Suern et all (एणा) & USA & $\mathrm{T}$ & $\mathrm{x}$ \\
\hline Mayer et al. (घण10I) & USA & $\mathrm{T}$ & $\mathrm{x}$ \\
\hline Mayer et al. (सा113) & USA & $\mathrm{T}$ & $\mathrm{x}$ \\
\hline De(Urea (पणII) & USA & $\mathrm{T}$ & $\mathrm{x}$ \\
\hline Dandy et al. (11997) & Australia & $\mathrm{F}$ & \\
\hline Arbués et al. (¿U103) & $\mathrm{N} / \mathrm{A}$ & $\mathrm{F}$ & \\
\hline Molinos-Senante (2प144) & Spain & $\mathrm{F}$ & \\
\hline Worthington and Hottman (2या118) & $\mathrm{N} / \mathrm{A}$ & $\mathrm{F}$ & \\
\hline Kanakouldis (ZUणZ) & Greece & $\mathrm{F}$ & \\
\hline Duke et all (20102) & USA & $\mathrm{F}$ & \\
\hline Hensher et al. (एवण0) & Australia & $\mathrm{L}$ & $\mathrm{x}$ \\
\hline Brennan et al, (सUण7) & Australia & $\mathrm{L}$ & \\
\hline Gratton and Ward (201118) & Australia & $\mathrm{L}$ & \\
\hline Renwick and Archibald ([1098) & USA & $\mathrm{L}$ & $\mathrm{x}$ \\
\hline Steg and Vlek (खण119) & $\mathrm{N} / \mathrm{A}$ & L-E & $\mathrm{x}$ \\
\hline Britton et all (《णI3) & Australia & M & $\mathrm{x}$ \\
\hline Garcia and Thomas (एवणI) & France & M & \\
\hline Brooks (12006) & $\mathrm{N} / \mathrm{A}$ & M & \\
\hline Fielding et al. (सU13) & Australia & $\mathrm{E}$ & $\mathrm{x}$ \\
\hline Benwick and (ireen (201011) & USA & $\mathrm{E}$ & \\
\hline Howarth and Butler (एव104) & UK & $\mathrm{E}$ & $\mathrm{x}$ \\
\hline 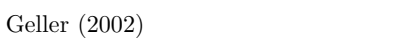 & $\mathrm{N} / \mathrm{A}$ & $\mathrm{E}$ & $\mathrm{x}$ \\
\hline Willis et all (सUIII) & Australia & $\mathrm{E}$ & $\mathrm{x}$ \\
\hline Froehlich et all (खणा2) & USA & $\mathrm{E}$ & $\mathrm{x}$ \\
\hline Sonderlund et all (खण14) & $\mathrm{N} / \mathrm{A}$ & $\mathrm{E}$ & $\mathrm{x}$ \\
\hline Kenney et al. (¿0104) & USA & $\mathrm{L}$ & \\
\hline Kenney et al. (एवपाष) & USA & $\mathrm{L}+\mathrm{F}+\mathrm{E}$ & $\mathrm{x}$ \\
\hline Mead and Aravinthan (खU1एप) & Australia & $\mathrm{T}$ & $\mathrm{x}$ \\
\hline Froes Lima and Portillo Navas (सU1:2) & Brazil & $\mathrm{T}+\mathrm{E}$ & $\mathrm{x}$ \\
\hline Carragher et al. (एणIV) & Australia & $\mathrm{T}$ & $\mathrm{x}$ \\
\hline Cole et all (सणाz) & Australia & $\mathrm{F}$ & $\mathrm{x}$ \\
\hline Stewart et all (सा1]3) & Australia & $\mathrm{E}$ & $\mathrm{x}$ \\
\hline Gurung et al. (एणा. & Australia & $\mathrm{T}$ & $\mathrm{x}$ \\
\hline Giacomoni and Berglund (सU. & USA & $\mathrm{L}+\mathrm{T}$ & \\
\hline Escriva-Boul et all (《ulbal) & $58 \mathrm{~A}$ & $\mathrm{~T}+\mathrm{E}$ & \\
\hline Escriva-Boul et all (20156) & USA & $\mathrm{T}+\mathrm{E}$ & \\
\hline
\end{tabular}


Table 6: Main research challenges for the use of smart meters in residential water demand modeling and management.

\begin{tabular}{|l|l|l|l|}
\hline 1) Data gathering & 2) Water end-uses characterization & 3) User modeling & 4) Personalized WDMS \\
\hline $\begin{array}{l}\text { 1.1) Management of big } \\
\text { data }\end{array}$ & $\begin{array}{l}\text { 2.1) Automatic } \\
\text { disaggregation } \\
\text { procedures (i.e., no } \\
\text { manual processing) }\end{array}$ & $\begin{array}{l}\text { 3.1) Matching observed } \\
\text { water consumption profiles } \\
\text { with potential drivers of } \\
\text { users' behaviors }\end{array}$ & $\begin{array}{l}\text { 4.1) More effective behavioral } \\
\text { influence via customized } \\
\text { feedbacks }\end{array}$ \\
\hline $\begin{array}{l}\text { 1.2) Centralized or } \\
\text { distributed information } \\
\text { system }\end{array}$ & $\begin{array}{l}\text { 2.2) Unsupervised } \\
\text { disaggregation } \\
\text { algorithms (i.e., no } \\
\text { ground truth) }\end{array}$ & $\begin{array}{l}\text { 3.2) Identification of spatial } \\
\text { patterns across geographical } \\
\text { areas }\end{array}$ & 4.2) Long-term effect of WDMS \\
\hline $\begin{array}{l}\text { 1.3) Impacts on } \\
\text { household privacy }\end{array}$ & $\begin{array}{l}2.3 \text { Higher accuracy in } \\
\text { reproducing timings and } \\
\text { frequencies }\end{array}$ & $\begin{array}{l}3.3) \text { Validation of the agent- } \\
\text { based behavioral models }\end{array}$ & $\begin{array}{l}\text { 4.3) Social norms and social } \\
\text { influence }\end{array}$ \\
\hline $\begin{array}{l}\text { 1.4) Real world scalability } \\
\text { of high-resolution networks }\end{array}$ & & $\begin{array}{l}3.4) \text { Testing experimental } \\
\text { trials and gamification } \\
\text { platforms }\end{array}$ & $\begin{array}{l}3.5) \text { Developing integrated } \\
\text { models for water and } \\
\text { water-related energy }\end{array}$ \\
\hline
\end{tabular}




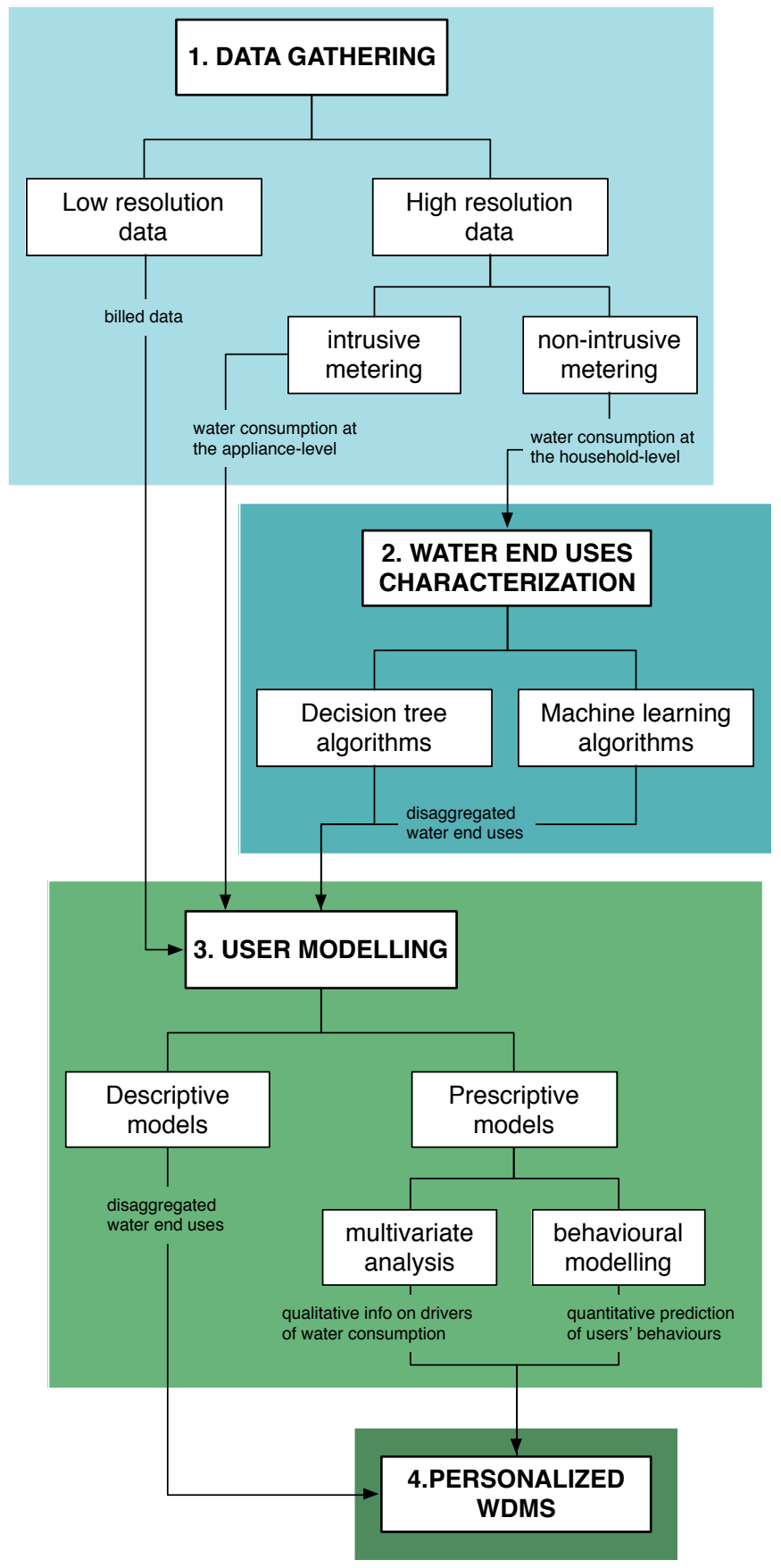

Figure 1: Flowchart of the general procedure for studying residential water demand management. 


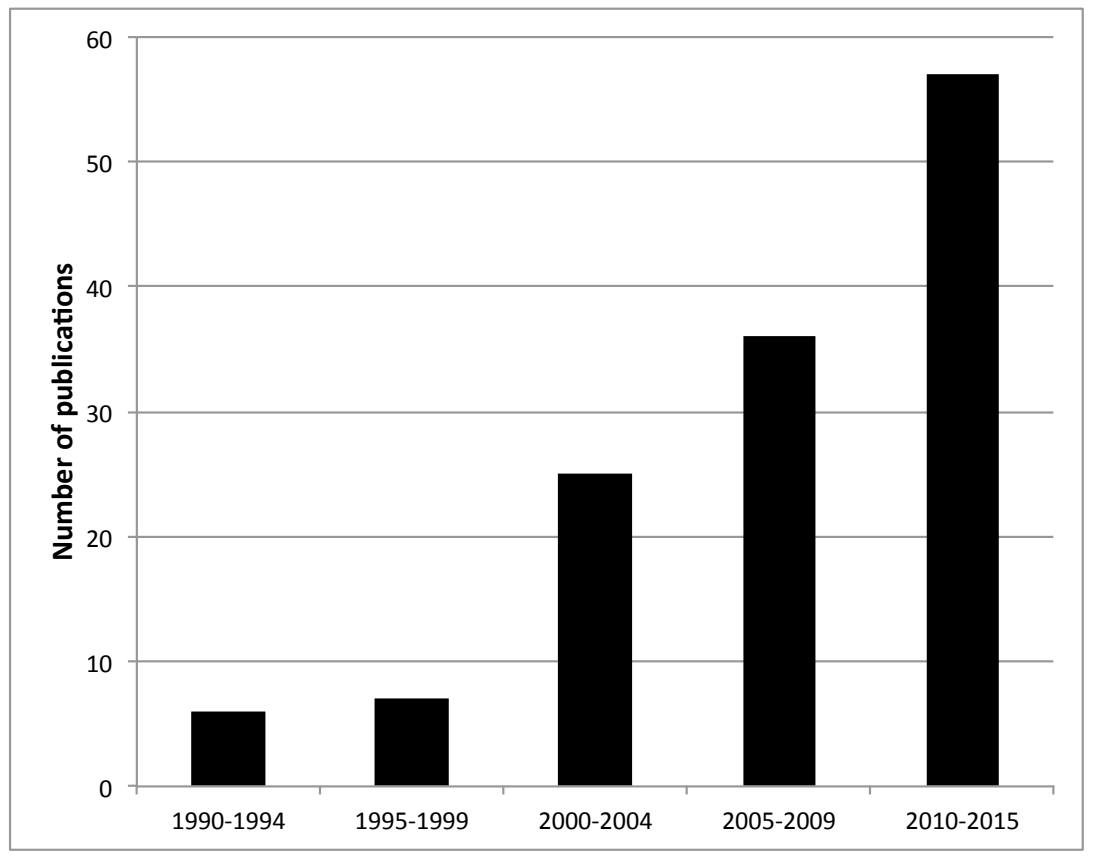

Figure 2: Five-years count of the 134 publications reviewed in this study. 